\title{
CHOSEN BIOTIC FACTORS INFLUENCING RAW COW MILK FREEZING POINT
}

\author{
O. Hanuš, Y. Zhang, M. Bjelka, J. Kučera, P. Roubal, R. Jedelská
}

Received: March 4, 2011

\begin{abstract}
HANUŠ, O., ZHANG, Y., BJELKA, M., KUČERA, J., ROUBAL, P., JEDELSKÁ, R.: Chosen biotic factors influencing raw cow milk freezing point. Acta univ. agric. et silvic. Mendel. Brun., 2011, LIX, No. 5, pp. 65-82

The milk freezing point depression (FPD) is important physical property. FPD is influenced by milk composition especially by components with osmotic pressure activity and by other physiological factors. There is possible to indicate a foreign (extraneous) water addition into milk by FPD. This is necessary to have a good estimated legislative FPD discrimination limit (FPD-L) for purpose of milk quality control. This paper was aimed at obtaining information to improve such estimation. Impacts factors as season variations, estimated state of dairy cow nutrition and some milk components and properties on milk FPD and their relations to FPD were quantified (n 11540 - 72607 bulk raw cow milk samples). The highest FPD was in Spring $\left(-0.52097 \pm 0.004877^{\circ} \mathrm{C}\right)$, the lowest in Autumn $(-0.52516 \pm$ $\left.0.005725^{\circ} \mathrm{C} ; \mathrm{P}<0.001\right)$. Correlation between FPD and lactose was $0.35(\mathrm{P}<0.001) .12 \%$ and $5.4 \%$ of FPD variability is explainable by lactose and casein variability. Relationship between FPD and urea (U) was $0.26(\mathrm{P}<0.001)$ in March. The worst FPD was in group with presupposed (according to milk urea and protein combination) nitrogen matter (NM) and energy $(\mathrm{E})$ insufficiency $\left(-0.51855 \pm 0.007288^{\circ} \mathrm{C}\right)$. The best FPD was in group with presupposed NM and E surplus in feeding ration $(-0.52536 \pm 0.004785$ ${ }^{\circ} \mathrm{C} ; \mathrm{P}<0.001$ ). The FPD was worse in suspicion on $\mathrm{E}$ deficiency (on the basis of fat/crude protein ratio) as compared to presumption for balanced E nourishment of dairy herds $\left(-0.52105 \pm 0.006436{ }^{\circ} \mathrm{C}>\right.$ $\left.-0.52244 \pm 0.005367^{\circ} \mathrm{C} ; \mathrm{P}<0.001\right)$. Results can improve the estimation of objective FPD-L.
\end{abstract}

dairy cow, bulk milk sample, freezing point depression, fat, protein, casein, energy metabolism estimation, lactose, solids non fat, somatic cell count, urea, free fatty acids

In general, the milk freezing point depression (FPD) is an important physical milk indicator (as it was published by Freeman and Bucy, 1967; Demott, 1969; Eisses and Zee, 1980; Brouwer, 1981; Walstra and Jenness, 1984; Koops et al., 1989; Rohm et al., 1991; Buchberger, 1990 a, b, 1991, 1994, 1997; Wiedemann et al., 1993; Bauch et al., 1993; Buchberger and Klostermeyer, 1995; Crombrugge, 2003) with typically very low variability under natural conditions. This fact is valid both for individual and especially for bulk milk samples. Under sure conditions FPD can be used as one of possible indicators for detection of addition of foreign (extraneous) water into raw or pasteurized milk (Eisses and Zee, 1980; Walstra and Jenness, 1984; Rohm et al., 1991; Buchberger, 1991 and 1997; MPR Bayern, 1993, 1994 and 1995; Hanuš et al.,
2003 a; Roubal et al., 2004; Rasmussen and Bjerring, 2005). Such extraneous water addition can be caused by unintentional mistake during milking or milk processing or by poor technological discipline at the milking or further processing procedure. It means for instance by an unexpected failure on milking or processing equipment or by poor milking equipment and poor procedure including bad intention of an operator during milking or technological milk treatment. The last mentioned reason means milk falsification in the food chain which is unacceptable generally on the first hand. On the other hand, there is necessary a clear specification about FPD in national food legislation in terms of objectivity at the mentioned control using of milk FPD value because it has significant influence on raw milk payment according to its 
quality very often. An acceptable solution supposes a good definition of FPD discrimination limit value and its use conditions for standard milk quality confirmation or refusing. It means the objectivity towards the milk producer and processor as well. It has been not fulfiled every time in the Czech Republic. An imbalance in this state is probably the main reason (Hanuš et al., 2003 a) why the problem of the milk FPD evaluation shows so called boomerang effect in terms of FPD importance for incidental strong discussions between relevant business partners on the milk market board. Of course, FPD as important quality indicator is also marker of general dairy food chain quality.

\section{Effects on milk FPD}

Proofs and reasoning about different aspects of milk FPD problem were shown as follows: - FPD essence and its relationships to milk composition and its osmotic pressure (Freeman and Bucy, 1967; Demott, 1969; Brouwer, 1981; Walstra and Jenness, 1984; Buchberger, 1990 a, b, 1991, 1994, 1997; Wiedemann et al., 1993; Hanuš et al., 2003 b; Crombrugge, 2003; Kirchnerová and Foltys, 2005; Kovárová et al., 2005; Chládek and Čejna, 2005; Hanuš et al., 2005 b, 2010, 2011 a; Macek et al., 2008); - principles of various FPD analytical measurements (Koops et al., 1989; Bauch et al., 1993; Buchberger, 1994; Buchberger and Klostermeyer, 1995; Crombrugge, 2003); - influences of mammal species, cattle breed and height of the dairy cow milk yield on FPD value (Buchberger, 1990 and 1997; Hanuš et al., 2003, 2009, 2010; Macek et al., 2008; Genčurová et al., 2008; Janštová et al., 2007); impacts of the nitrogen matter/energy and mineral element balance in the dairy cow nutrition on the FPD (Buchberger, 1990, 1991 and 1997; Hanuš et al., 1998, 2010; Kološta, 2003); - effects of production disorder occurrence including milk secretion disorders and SCC (mastitis) on FPD variation (Eisses and Zee, 1980; Buchberger, 1990 and 1997; Hanuš et al., 2003; Chládek and Čejna, 2005; Macek et al., 2008); - technological impacts (farm and processing) and foreign water addition into milk on FPD levels (Eisses and Zee, 1980; Rohm et al., 1991; Buchberger, 1991 and 1997; Hanuš et al., 2003 a; Roubal et al., 2004; Rasmussen and Bjerring, 2005). For instance there was stated that (MPR Bayern, 1993, 1994 and 1995) beside the foreign water addition reason (which occurred from 34.5 to $41.2 \%$ of incidents of studied cases only) the FPD values had been deteritorated mostly by the poor nutrition of dairy cows (from 50.2 to $58.8 \%$ of cases) in Bavaria. The knowledge about most of incidental influence factors on FPD under actual circumstances, which are on good level, create very important basis for the future correct FPD discrimination limit derivation.

\section{Necessity for correct revision of legislative milk FPD discrimination limit}

FPD discrimination limits, which are used officially and/or conventionally for standard milk quality confirmation differ mutually in dependence on historical and geographical points of view, namely from $\leq-0.530{ }^{\circ} \mathrm{C}$ (in the $\mathrm{CR}$ at the lucidly lower milk yield level of dairy cows as compared to today state; Klíčník, 1978) to $\leq-0.505{ }^{\circ} \mathrm{C}$ and $\leq-0.500{ }^{\circ} \mathrm{C}$ (valid in the Netherlands and Norway; Bossuyt, 2003 and Tomáška et al., 2005). However, the mostly used actual FPD discrimination limits vary between $\leq-0.520^{\circ} \mathrm{C}$ (EEC 92/46 and Regulation 853; for instance in Denmark, Great Britain, Sweden and so on) and $\leq-0.515^{\circ} \mathrm{C}$ (for instance in Germany (Bavaria), Austria and Switzerland; Buchberger, 1990 and 1997; Rohm et al., 1991; Hanuš et al., 2003 a). For example now, there is used the FPD discrimination limit with the value $\leq-0.510^{\circ} \mathrm{C}$ in Belgium (Bossuyt, 2003). Also there are used other exceptional limits as well. For instance $\leq-0.512{ }^{\circ} \mathrm{C}$ (Cyprus) and $\leq-0.500{ }^{\circ} \mathrm{C}$ (Norway), as it was summarized by Tomáška et al. (2005). Today we are using alternatively $\leq-0.520^{\circ} \mathrm{C}$ or $\leq-0.515^{\circ} \mathrm{C}$ (ČSN 570529 ; the Regulations 203/2003 Coll. about veterinary demands on milk and milk products and 638/2004 and 1234/2007; Hanuš et al., 2003 a, b; Roubal et al., 2004) for raw and pasteurized milk in the Czech Republic. There is prescribed for mean of drinking milk FPD the value according to raw milk under local conditions of collecting area in 1234/2007. Nevertheless, the value $\leq-0.520{ }^{\circ} \mathrm{C}$ is not in the reasonable accordance with the fact state (Hanuš et al., 2003 a), as the country average values were determined $-0.5231,-0.5236^{\circ} \mathrm{C}$ and -0.5271 (2003, 2004 and 2009) in the bulk milk samples (Roubal, Kopunecz, Pešinová et al., 2004 and 2005, Kopunecz, 2010). It means, that 28.6\% (2002), 23.5\% (2003), 20.1\% (2004) and $8.7 \%$ (2009) of raw cow milk deliveries into dairy plants were not in the accordance with the FPD discrimination limit $\leq-0.520^{\circ} \mathrm{C}$ and $5.1 \%$, $5.1 \%, 4.4 \%$ and $2.5 \%$ with the limit $\leq-0.515^{\circ} \mathrm{C}$. There are too high percentages about the first limit and still higher in the second case of the limit in order to be really all caused by the foreign watter additions into milk. There were the full $38 \%$ of unsatisfactory cases at the limit $\leq-0.520{ }^{\circ} \mathrm{C}$ for raw cow milk in Slovakia (2004) as it was stated by Tomáška et al. (2005), too. Further, recently it was also stated by the screening that $37 \%$ of collected pasteurized drinking milk samples did not meet the FPD discrimination limit $\leq-0.515{ }^{\circ} \mathrm{C}$ and also $65 \%$ of them did not meet the limit $\leq-0.520{ }^{\circ} \mathrm{C}$ in the Czech Republic (Roubal et al., 2004). In consideration of above mentioned facts, it is quite clear that a new correct revision of FPD discrimination limit is necessary in the Czech Republic. This is possible to do it only on the basis of exact scientific evaluation in terms of today fact situation and incidental impacts of different interferential factors and effects. Also for an incidental application on European Commission to reach an exception with regard to officially valid FPD discrimination limit it is necessary to support such material by the relevant actual scientific proofs and warrant. 


\section{Aim of the paper in terms of milk FPD interpretation}

In general, it is well known that in less favourable areas (LFA, in terms of agriculture land exploitation), there could be problems with the dairy cow energy supplementation by their feeding rations on the basis of local feed sources. In this consequences there could be more difficult to meet the legislative limit of milk FPD for standard milk quality reaching in some of dairy herds. Such are reasons why it is important to define this FPD legislative discrimination limit in the right way under country specific conditions. Therefore the aim of this paper was to analyse the relationships between FPD and energy metabolism markers of dairy cows in their milk (such as milk citric acid content, milk F/CP ratio or combination classes of milk urea and protein contents). The second reason is to contribute to correct legislation FPD discrimination limit definition for standard milk quality under the Czech Republic conditions.

Regarding above mentioned facts this is quite clear that more actual studies are necessary for the explanation of relationships between FPD values and milk composition, milk markers for health state and nutrition of dairy cows and farmer factors under domestic conditions.

\section{MATERIAL AND METHODS}

\section{Evaluated set of bulk milk samples}

Bulk milk samples of large data set were obtained regularly (once or more times per month) from commercial dairy herds for milk quality determination (mostly according to standard ČSN 57 0529) in the framework of official milk payment system during twelve calendar months. Samples were treated by low temperature about $6{ }^{\circ} \mathrm{C}$ and immediately transported into accredited milk laboratory. Generally, the milk samples were analysed in accordance with relevant standard operation procedure manuals of laboratory. Milk samples came from both milked populations of dairy cows in the country, Holstein and Czech Fleckvieh cattle. There were investigated different numbers of milk samples for various indicators. Maximal sample number was for FPD and some other milk indicators $(n=72607)$ and minimal for free fatty acids (FFA; $n=11$ 540).

\section{Investigated milk indicators with their abbreviations and units}

Measured and calculated tested milk indicators were as follows on the list of abbreviations and used units: FPD = milk freezing point depression $\left({ }^{\circ} \mathrm{C}\right) ; \mathrm{F}=$ milk fat content ( $\left.\mathrm{g} .100 \mathrm{ml}^{-1} ; \%\right) ; \mathrm{L}=$ lactose content (monohydrate; g.100 ml-1; \%); SNF = solids non fat content (g.100 ml-1; \%); DM = dry matter $\left(\mathrm{g} .100 \mathrm{ml}^{-1}\right.$;

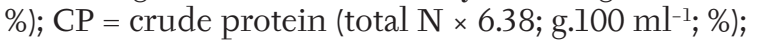
CAS = casein $\left(\right.$ casein $\mathrm{N} \times 6.38 ;$ g.100 $\left.\mathrm{ml}^{-1} ; \%\right)$; SCC = somatic cell count (ths.ml-1); F/CP = ratio between fat and crude protein; $\mathrm{U}=$ urea concentration (mmol. $\left.\mathrm{l}^{-1}\right) ; \quad$ FFA $=$ concentration of free fatty acids $\left(\mathrm{mmol} .100 \mathrm{~g}^{-1}\right)$ in milk fat.

\section{Used dairy analytical methods}

FPDs were measured by two analytical methods. The first was carried out with MilkoScan 6000 system (Foss Electric, Denmark). This was adjusted according to reference cryoscopic method results in regular intervals. Such procedure was described for example by Crombrugge (2003) and Tomáška et al. (2005) as alternative measurement of milk FPD equivalent. The second measurement procedure was performed by the own cryoscopic method (ČSN 57 0538, ISO 5764:2002(E)), which was instrument Cryo-Star automatic Funke-Gerber (Germany). It was realized at this part of analysed milk samples, which afforded suspicious values by the first indirect measurement method. The selected measurement mood was reference Plateau Search in this case. The used instrument was under regular calibration by the standard $\mathrm{NaCl}$ solutions and took part in the national proficiency testing with successful results regularly. The incidental interferential effects were controlled (in accordance with Bauch et al., 1993; Koops et al., 1989; Buchberger and Klostermeyer, 1995; Crombrugge, 2003).

The other investigated milk parameters as the F, L, CP, CAS, DM, SNF, U, FFA were measured by the instrument MilkoScan 6000 (Foss Electric, Denmark; MIR-FT = mid infra red spectrophotometric apparatus with the mathematics evaluation of whole IR spectrum by the Fourier's transformations), which was regularly calibrated according to the reference method results (standard ČSN 570536 by the Gerber's method for fat content, Kjeldahl's method for crude protein content (with previous experience by Hanuš et al., 1995) and polarimetric and gravimetric methods for lactose and SNF contents, according to standard ČSN 57 0530; for $U$ and FFA according to direct ureolytic, photometrical and titration method results). The SCC was determined by the Fossomatic instrument (Foss Electric, Denmark) according to the standard ČSN EN ISO 13366-3. Both the previously mentioned instruments took part in the relevant national proficiency testing with the good results regularly.

\section{Performed statistical procedures}

The validation of the large data set was carried out by the determination of discrimination limits for all milk indicators. These limit values were derived from mean values and variability measure as $\mathrm{x} \pm 1.96$ or $2.58 \times \mathrm{sd}$, which included 95 or $99 \%$ of likelihood, that values belong into data set. If it was not possible, for example due to expressive deviation of data distribution from normal frequency distribution, another procedure was chosen, including the application of a qualified estimation. The valid data set (I) was applied for 
most kinds of evaluations. Further, the data set was adjusted (II) for presupposition of no water addition according to our recent results (Hanuš et al., 2003 a). This set was used for another kinds of evaluation in the framework of this paper. For these purposes all the milk samples with FPDs higher as $-0.513{ }^{\circ} \mathrm{C}$ were excluded out of some statistical evaluation.

The main statistical characteristics, such as arithmetical (x) and geometrical mean (xg), standard deviation (sd) and coefficient of variation (vx), were calculated in the month data sets. If necessary, the milk indicator (SCC in this case) data were logarithmically transformed before statistical evaluation of the main statistical characteristics and mutual relationships because of no presumption of normal data frequency distribution (Meloun and Militký, 1992 and 1994; Kupka, 1997; Hanuš et al., 2001).

The FPD value frequency distribution of whole data sets (I and II) were tested in terms of the normality by the $\mathrm{Q}$ and $\mathrm{Q}-\mathrm{Q}$ graphs as part of the exploratory analyse (Meloun and Militký, 1992 and 1994; Kupka, 1997). It was carried out in the month data sets. The third and fourth (tercial and quarter) central statistical moments of FPD data file, it means the obliqueness and acuteness (excess) were tested as well. The linear and non linear (logarithmical, exponential, quadratical and polynomical in terms of second or third degree) regressions were used at the testing and rendering of the relationships between the FPD (in $\mathrm{m}^{\circ} \mathrm{C} \times(-1)$ ) and the other milk indicators in the month data sets. It was expressed by the relevant regression equations (with highest statistical recovery in terms of concrete relationship explanation - determination coefficient) and coefficients or indexes of correlation.

The FPD data were rendered in milk urea and protein combination classes (as diagnostic parameter of dairy cow nutrition in terms of their nitrogen matter and energy maintenance (overloading or malnutrition), it means N/E nutrition balance, according to works of Kirchgessner et al., 1985 and 1986 or Illek and Pechová, 1997) by the box graph. The same strategy was used at the evaluation of influence of presupposed dairy cow energy metabolism on FPD according to F/CP ratio, too. The box graph with statistical testing was used for the seasonal effect evaluation as well. In the relevant box graphs: the median as the middle point value is demonstrated by central line; the upper and lower margins of the box are expressing the upper margin of the first and third quartiles, it means $50 \%$ central quantile; the abscissa is expressing the variation range as the difference between maximal and minimal value. The statistical significance of impacts on FPD was tested by the Student's t-test criterion.

\section{RESULTS AND DISCUSSION}

\section{General description of bulk milk sample data set}

The main statistical parameters of month data sets of all evaluated milk indicators of I data file are shown in Tab. I. The largest variability was observed at milk $U$ and SCC, usually over 30 and 50\%. The other variation coefficients were mostly below $10 \%$. The all average values are in accordance with good raw milk quality. All FPD month data sets of II data file and most of I data file were deviated $(\mathrm{P} \leq 0.05)$ as compared to the normal standard frequency distribution. It means from conventional model. It was caused due to obliqueness and acuteness as well. Only at three month data sets (June, July and August) of I data file (with a possible foreign watter addition) no significant $(P>0.05)$ deviations from normality were discovered at obliqueness (difference from zero). The biggest difference from normality $(\mathrm{P} \leq 0.05)$ was observed in January in terms of obliqueness, which is more important for statistical testing as compared to acuteness. During whole year the obliqueness varied around zero as central position. The mentioned June and January month data sets (file I) were selected as the best and worst result examples in terms of recovery of obliqueness normality for rendering by the Q and Q-Q graphs (Fig. 1 and Fig. 2). The deviations from standard curve (in the case of $Q$ graph) and diagonal line (in the case of $\mathrm{Q}-\mathrm{Q}$ graph) are expressing the differences from normality (considering obliqueness and acuteness) and their character in the figures. In spite of that fact, that most cases differ significantly from normal frequency distributin. This is valid in particular for less important acuteness. The deviations for more important obliqueness are practically irrelevant. That is reason, why it is possible to conclude, that any FPD value transformations are not necessary for next classical statistical testing evaluation and arithmetical mean and standard deviation use as main data set representatives is suitable.

\section{Milk freezing point regarding seasonal effect}

The seasonal effect on FPD is rendered in Fig. 3 and 4. The highest (the worst) average FPD was noted in Spring $\left(-0.52097 \pm 0.004877{ }^{\circ} \mathrm{C}\right.$; variation coefficient $=0.9 \% ; \mathrm{n}=12524$ ). The lowest (the best) FPD was investigated in Autumn $(-0.52516 \pm$ $0.005725{ }^{\circ} \mathrm{C}$; variation coefficient $=1.1 \% ; \mathrm{n}=12054$ ) . The difference in FPD between these two seasonal periods was statistically significant $(\mathrm{t}=61.9$ and $\mathrm{P}<$ 0.001 ). There are six pair combinations of differences between seasonal periods. All these differences were statistically tested. In particular because of the high number of cases in the individual seasonal groups all the differences were statistically significant $(\mathrm{P}<$ 0.001). In general, the seasonal effect on FPD was confirmed as highly significant, similarly to the results, which were reported by Roubal et al. (2004, 2005), Hanuš et al. (2005) and Kopunecz (2010). 
I: Main statistical parameters of raw cow bulk milk sample indicators in months during year in validated data file (I, whole set)

\begin{tabular}{|c|c|c|c|c|c|c|c|c|c|c|c|c|c|}
\hline & & FPD & $\mathbf{F}$ & $\mathbf{L}$ & SNF & DM & $\mathbf{C P}$ & CAS & $\mathbf{U}$ & FFA & SCC & $\log \mathrm{SCC}$ & $\mathbf{F} / \mathbf{C P}$ \\
\hline & & \multicolumn{12}{|c|}{ 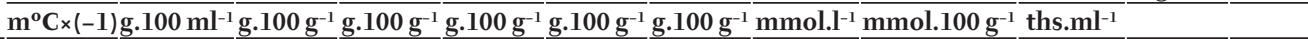 } \\
\hline \multirow{5}{*}{ January } & $\mathbf{n}$ & 4937 & 6464 & 6481 & 6482 & 6388 & 6479 & 6481 & 6325 & & 6302 & 6302 & 6427 \\
\hline & $\mathbf{x}$ & 522 & 4.17 & 4.93 & 8.91 & 13.15 & 3.42 & 2.51 & 3.22 & & 228 & 2.2986 & 1.22 \\
\hline & $\mathrm{xg}$ & & & & & & & & & & & 199 & \\
\hline & $\mathbf{s x}$ & 5.771 & 0.385 & 0.093 & 0.239 & 0.453 & 0.185 & 0.151 & 1.306 & & 125.736 & 0.2342 & 0.115 \\
\hline & $\mathbf{v x}$ & 1.1 & 9.2 & 1.9 & 2.7 & 3.4 & 5.4 & 6.0 & 40.6 & & 55.1 & 10.2 & 9.4 \\
\hline \multirow{5}{*}{ February } & $\mathbf{n}$ & 6477 & 6469 & 6490 & 6502 & 6390 & 6506 & 6504 & 6321 & & 6386 & 6386 & 6438 \\
\hline & $\mathbf{x}$ & 522 & 4.13 & 4.96 & 8.93 & 13.14 & 3.41 & 2.48 & 3.81 & & 246 & 2.3323 & 1.21 \\
\hline & $\mathrm{xg}$ & & & & & & & & & & & 215 & \\
\hline & sx & 4.733 & 0.376 & 0.091 & 0.237 & 0.450 & 0.184 & 0.150 & 1.306 & & 133.842 & 0.2331 & 0.114 \\
\hline & $\mathbf{v x}$ & 0.9 & 9.1 & 1.8 & 2.7 & 3.4 & 5.4 & 6.0 & 34.3 & & 54.4 & 10.0 & 9.4 \\
\hline \multirow{5}{*}{ March } & $\mathbf{n}$ & 5760 & 5769 & 5791 & 5797 & 5709 & 5803 & 5397 & 5783 & & 6097 & 6097 & 5744 \\
\hline & $\mathbf{x}$ & 523 & 4.06 & 4.99 & 8.90 & 13.07 & 3.38 & 2.47 & 4.16 & & 245 & 2.3345 & 1.20 \\
\hline & $\mathrm{xg}$ & & & & & & & & & & & 216 & \\
\hline & $\mathbf{s x}$ & 5.159 & 0.357 & 0.092 & 0.239 & 0.437 & 0.185 & 0.149 & 1.564 & & 124.741 & 0.2268 & 0.107 \\
\hline & $\mathbf{v x}$ & 1.0 & 8.8 & 1.8 & 2.7 & 3.3 & 5.5 & 6.0 & 37.6 & & 50.9 & 9.7 & 8.9 \\
\hline \multirow{5}{*}{ April } & $\mathbf{n}$ & 6223 & 6241 & 6245 & 6271 & 6163 & 6272 & 6275 & 6048 & & 6202 & 6202 & 6215 \\
\hline & $\mathbf{x}$ & 521 & 4.03 & 5.00 & 8.86 & 13.00 & 3.35 & 2.44 & 4.16 & & 255.03 & 2.3525 & 1.20 \\
\hline & $\mathrm{xg}$ & & & & & & & & & & & 225 & \\
\hline & sx & 4.907 & 0.354 & 0.085 & 0.245 & 0.429 & 0.184 & 0.148 & 1.370 & & 129.702 & 0.2248 & 0.111 \\
\hline & $\mathbf{v x}$ & 0.9 & 8.8 & 1.7 & 2.8 & 3.3 & 5.5 & 6.1 & 32.9 & & 50.9 & 9.6 & 9.2 \\
\hline \multirow{5}{*}{ May } & $\mathbf{n}$ & 6301 & 6316 & 6338 & 6339 & 6242 & 6337 & 6341 & 6152 & & 6279 & 6279 & 6278 \\
\hline & $\mathbf{x}$ & 521 & 3.91 & 4.99 & 8.80 & 12.83 & 3.30 & 2.41 & 4.08 & & 261 & 2.3583 & 1.18 \\
\hline & $\mathrm{xg}$ & & & & & & & & & & & 229 & \\
\hline & sx & 4.847 & 0.351 & 0.082 & 0.217 & 0.409 & 0.161 & 0.131 & 1.454 & & 139.386 & 0.2330 & 0.110 \\
\hline & $\mathbf{v x}$ & 0.9 & 9.0 & 1.6 & 2.5 & 3.2 & 4.9 & 5.4 & 35.6 & & 53.4 & 9.9 & 9.3 \\
\hline \multirow{5}{*}{ June } & $\mathbf{n}$ & 6204 & 6401 & 6419 & 6375 & 6331 & 6422 & 6430 & 6228 & & 6114 & 6114 & 6365 \\
\hline & $\mathbf{x}$ & 520 & 3.83 & 4.99 & 8.72 & 12.69 & 3.24 & 2.36 & 3.62 & & 288 & 2.3993 & 1.18 \\
\hline & $\mathrm{xg}$ & & & & & & & & & & & 251 & \\
\hline & sx & 5.516 & 0.336 & 0.082 & 0.206 & 0.397 & 0.155 & 0.125 & 1.274 & & 154.560 & 0.2364 & 0.107 \\
\hline & $\mathbf{v x}$ & 1.1 & 8.8 & 1.6 & 2.4 & 3.1 & 4.8 & 5.3 & 35.2 & & 53.7 & 9.9 & 9.0 \\
\hline \multirow{5}{*}{ July } & $\mathbf{n}$ & 6425 & 6432 & 6444 & 6431 & 6354 & 6447 & 6455 & 6211 & & 6342 & 6342 & 6391 \\
\hline & $\mathbf{x}$ & 520 & 3.85 & 4.98 & 8.73 & 12.72 & 3.27 & 2.37 & 4.15 & & 271 & 2.3684 & 1.18 \\
\hline & $\mathrm{xg}$ & & & & & & & & & & & 234 & \\
\hline & $s \mathbf{x}$ & 5.133 & 0.321 & 0.086 & 0.219 & 0.389 & 0.156 & 0.127 & 1.259 & & 153.185 & 0.2463 & 0.102 \\
\hline & $\mathbf{v x}$ & 1.0 & 8.4 & 1.7 & 2.5 & 3.1 & 4.8 & 5.3 & 30.4 & & 56.4 & 10.4 & 8.6 \\
\hline \multirow{5}{*}{ August } & $\mathbf{n}$ & 6292 & 6293 & 6310 & 6268 & 6213 & 6324 & 6325 & 6087 & & 6181 & 6181 & 6260 \\
\hline & $\mathbf{x}$ & 521 & 3.86 & 4.96 & 8.70 & 12.71 & 3.27 & 2.35 & 4.17 & & 303 & 2.4230 & 1.18 \\
\hline & $\mathrm{xg}$ & & & & & & & & & & & 265 & \\
\hline & sx & 4.994 & 0.338 & 0.093 & 0.225 & 0.407 & 0.160 & 0.130 & 1.295 & & 157.637 & 0.2361 & 0.106 \\
\hline & $\mathbf{v x}$ & 1.0 & 8.8 & 1.9 & 2.6 & 3.2 & 4.9 & 5.5 & 31.1 & & 52.1 & 9.7 & 9.0 \\
\hline \multirow{5}{*}{ September } & $\mathbf{n}$ & 6234 & 6208 & 6239 & 6186 & 6135 & 6239 & 6257 & 6048 & & 6203 & 6203 & 6171 \\
\hline & $\mathbf{x}$ & 523 & 3.99 & 4.90 & 8.83 & 12.91 & 3.40 & 2.55 & 4.00 & & 280 & 2.3926 & 1.18 \\
\hline & $\mathrm{xg}$ & & & & & & & & & & & 247 & \\
\hline & sx & 5.546 & 0.343 & 0.105 & 0.239 & 0.417 & 0.176 & 0.145 & 1.448 & & 147.094 & 0.2262 & 0.104 \\
\hline & $\mathbf{v x}$ & 1.1 & 8.6 & 2.1 & 2.7 & 3.2 & 5.2 & 5.7 & 36.2 & & 52.5 & 9.5 & 8.9 \\
\hline \multirow{5}{*}{ October } & $\mathbf{n}$ & 6143 & 6150 & 6177 & 6144 & 6104 & 6165 & 6166 & 5906 & & 6129 & 6129 & 6121 \\
\hline & $\mathbf{x}$ & 524 & 4.15 & 4.91 & 9.05 & 13.19 & 3.51 & 2.67 & 4.41 & & 253 & 2.3494 & 1.18 \\
\hline & $\mathrm{xg}$ & & & & & & & & & & & 224 & \\
\hline & sx & 5.779 & 0.374 & 0.112 & 0.255 & 0.448 & 0.183 & 0.117 & 1.393 & & 132.856 & 0.2221 & 0.110 \\
\hline & $\mathbf{v x}$ & 1.1 & 9.0 & 2.3 & 2.8 & 3.4 & 5.2 & 4.4 & 31.6 & & 52.5 & 9.5 & 9.3 \\
\hline & $\mathbf{n}$ & 5911 & 5926 & 5932 & 5852 & 5852 & 5924 & 5930 & 5811 & 5840 & 5874 & 5874 & 5887 \\
\hline & $\mathbf{x}$ & 526 & 4.25 & 4.95 & 9.17 & 13.35 & 3.52 & 2.71 & 3.32 & 0.614 & 256 & 2.3519 & 1.21 \\
\hline November & $\mathrm{xg}$ & & & & & & & & & & & 225 & \\
\hline & sx & 5.581 & 0.378 & 0.105 & 0.246 & 0.455 & 0.193 & 0.122 & 1.234 & 0.458 & 138.006 & 0.2257 & 0.105 \\
\hline & $\mathbf{v x}$ & 1.1 & 8.9 & 2.1 & 2.7 & 3.4 & 5.5 & 4.5 & 37.2 & 74.7 & 54.0 & 9.6 & 8.7 \\
\hline & $\mathbf{n}$ & 5700 & 5692 & 5707 & 5669 & 5632 & 5709 & 5710 & 5733 & 5746 & 5658 & 5658 & 5671 \\
\hline & $\mathbf{x}$ & 523 & 4.14 & 4.88 & 9.03 & 13.10 & 3.45 & 2.66 & 3.62 & 0.835 & 254 & 2.3506 & 1.20 \\
\hline December & $\mathrm{xg}$ & & & & & & & & & & & 224 & \\
\hline & sx & 5.9150 & 0.359 & 0.114 & 0.247 & 0.439 & 0.193 & 0.122 & 1.400 & 0.491 & 133.789 & 0.2240 & 0.107 \\
\hline & $\mathbf{v x}$ & 1.1 & 8.7 & 2.3 & 2.7 & 3.4 & 5.6 & 4.6 & 38.7 & 58.8 & 52.6 & 9.5 & 8.9 \\
\hline
\end{tabular}

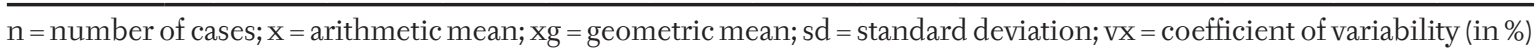




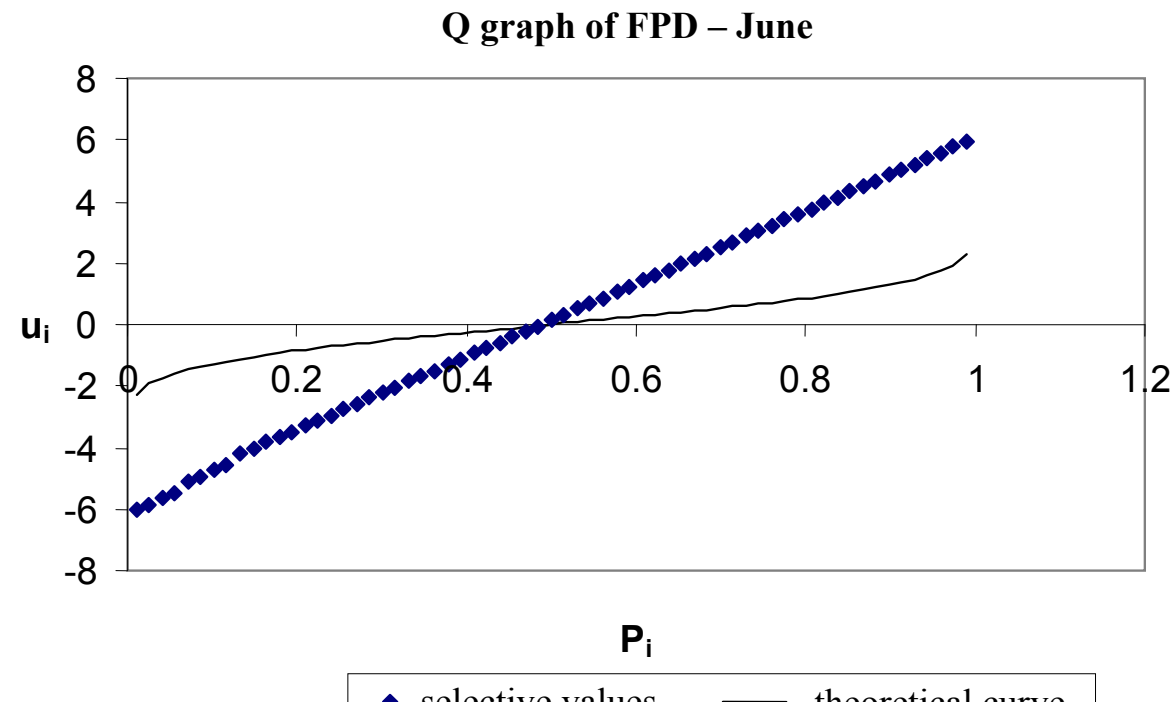

1: The quantile graph of the real data set of the milk freezing point value distribution (file I, June) $\mathrm{u}_{\mathrm{i}}=$ standard quantils of original data; $\mathrm{P}_{(\mathrm{i})}=$ order probability

\section{Q-Q graph of FPD - June}

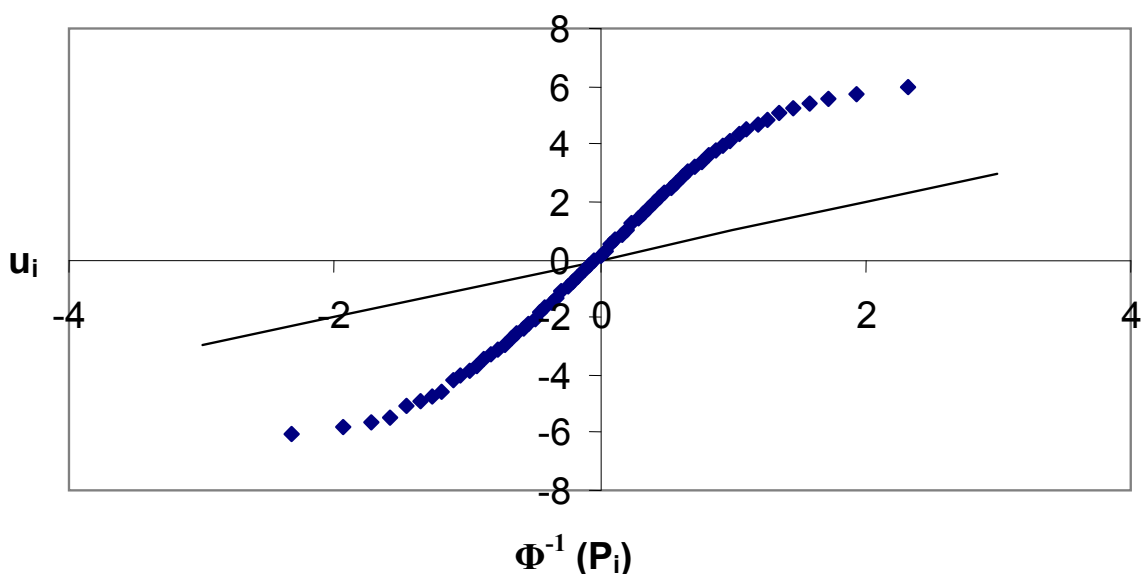

- selective values — theoretical line

2: The quantil-quantile graph of the distribution normality test for the data set of the milk freezing point values (file I, June)

$\mathrm{u}_{\mathrm{i}}=$ standard quantils of original data; $\Phi^{-1}(\mathrm{P})=$ theoretical quantils of standard normal distribution

It could be probably influenced by nutrition and temperature effect variations, despite using of total mixed ration on the basis of preserved fodder feedstuffs for nourishment of dairy cow herds during whole year.

\section{Description and interpretation of relationships between FPD and other health and milk indicators of dairy cow herds}

In general, the limitation of data file I range towards file II decreased all relationships between FPD and other milk quality indicators in terms of their tightness. The month relationships between FPD and fat content (file I) were very weak and coefficient of determination $\left(\mathrm{R}^{2}\right)$ varied from zero up to 0.013 $(\mathrm{r}=-0.11 ; \mathrm{P}<0.01$; Tab. II $)$ in July. However, the indicators were practically almost independent. The more relevant relationships $\left(\mathrm{R}^{2}\right)$ were stated between FPDs and crude protein contents, where varied from 0.0059 in August to 0.0408 in January. This second is equal to coefficient of correlation $0.20(\mathrm{P}<0.001$; Tab. II). It means slow consistent improvement 


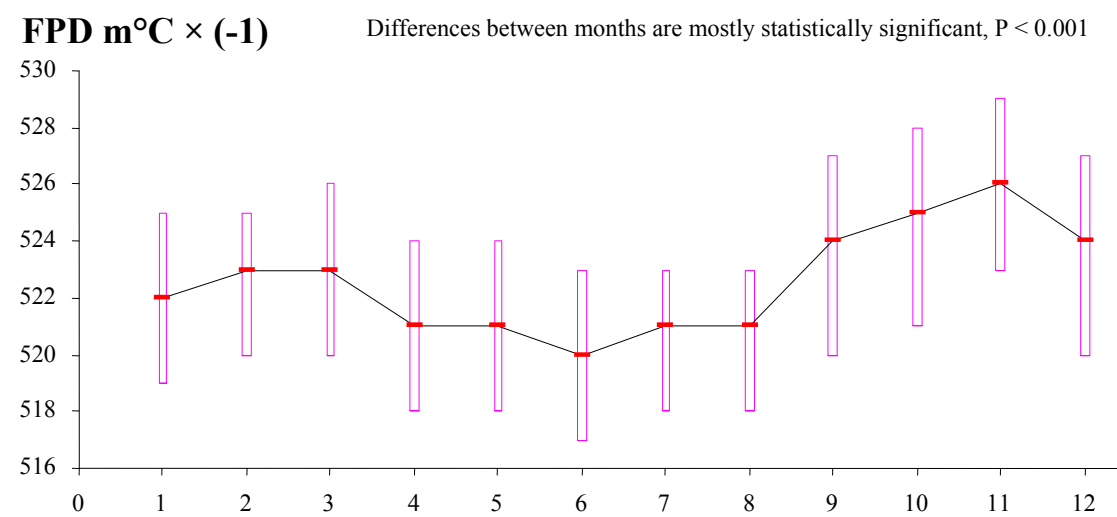

3: Calendar month effect on raw cow milk freezing point depression (FPD) in the Czech Republic (bulk milk samples, $n=72$ 607)

Month differences in sets are rendered by box graphs for good expression of data frequency distribution with median (central line) and 50\% central quantile (the box).

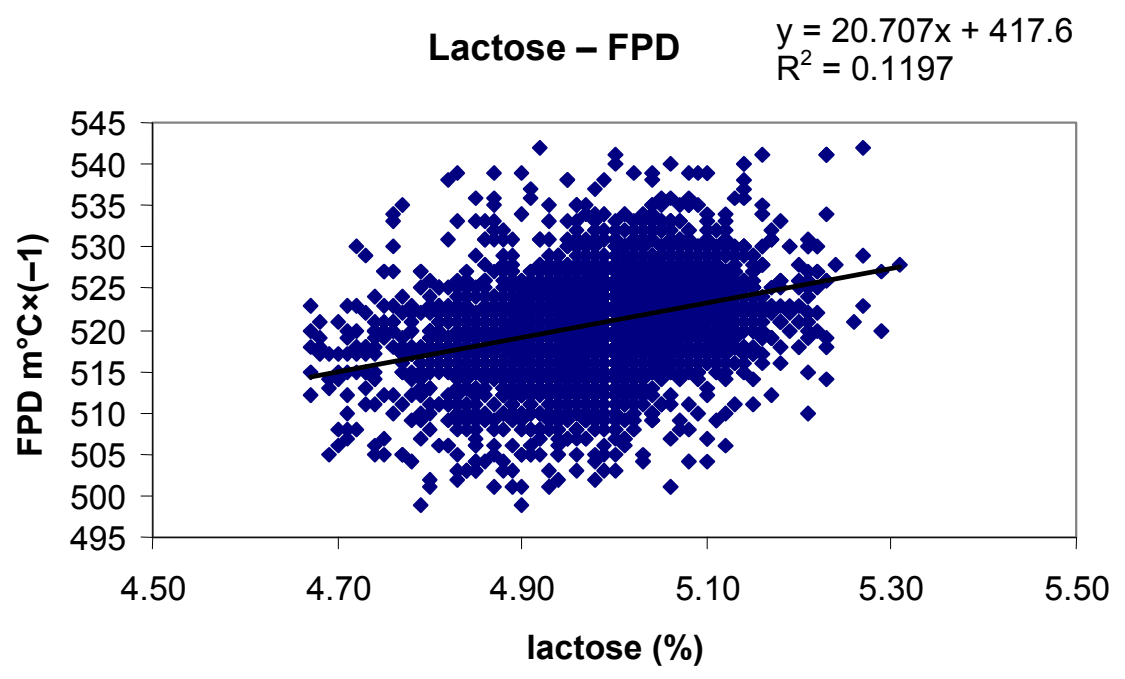

$$
\begin{array}{ll}
\text { Lactose - FPD - May } & y=14.753 x+447.92 \\
R^{2}=0.0828
\end{array}
$$

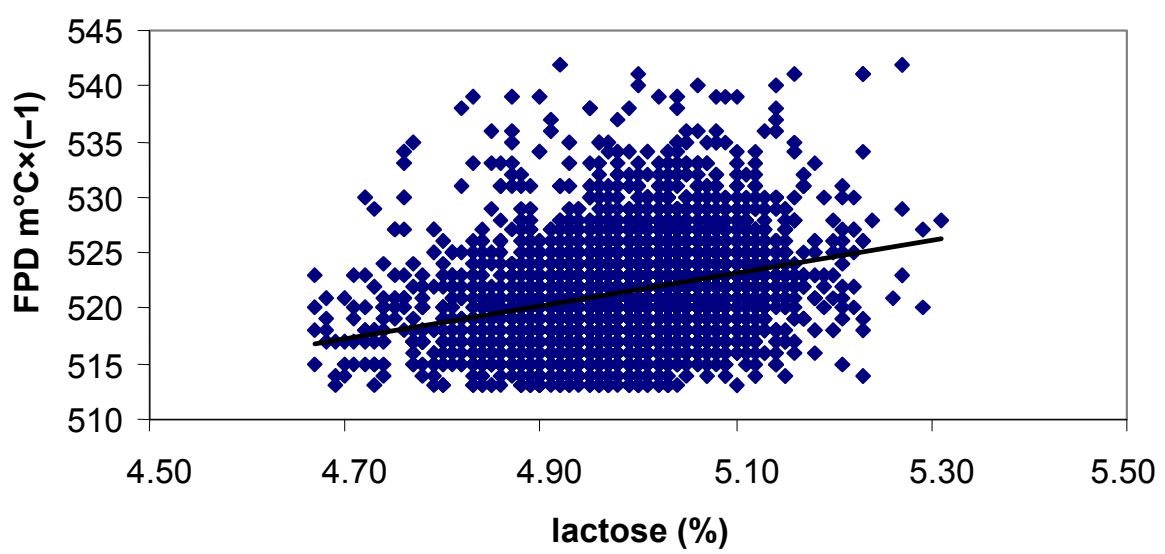

$\mathrm{r}=0.29 * * *$

4: The relationship between FPD and lactose content in whole (I, validated data set) and adjusted (II, validated data set, FPD $\leqq-0.513{ }^{\circ} \mathrm{C}$ ) set in May 
II: Selected month regression relationships between milk freezing point depression and sure milk quality indicators in the bulk milk samples

\begin{tabular}{|c|c|c|c|c|c|c|c|}
\hline Relationship & Data file & Month & Type of relationship & Equation & $\mathbf{R}^{2}$ & $\mathbf{r}$ & Significance \\
\hline $\mathrm{FPD} \times \mathrm{F}$ & I & July & linear & $y=-0.5673 x+522.69$ & 0.0130 & -0.11 & $* *$ \\
\hline $\mathrm{FPD} \times \mathrm{CP}$ & I & January & linear & $y=6.1696 x+500.87$ & 0.0408 & 0.20 & $* *$ \\
\hline $\mathrm{FPD} \times \mathrm{L}$ & I & May & poweral & $y=378.79 x^{0.1982}$ & 0.1200 & 0.35 & $* *$ \\
\hline $\mathrm{FPD} \times \mathrm{DM}$ & I & January & linear & $y=1.6271 x+500.61$ & 0.0167 & 0.13 & $* *$ \\
\hline $\mathrm{FPD} \times \mathrm{DM}$ & I & January & poweral & $y=468.51 x^{0.042}$ & 0.0174 & 0.13 & $* *$ \\
\hline $\mathrm{FPD} \times \mathrm{F} / \mathrm{CP}$ & I & January & linear & $y=-6.4255 x+529.83$ & 0.0170 & -0.13 & $* *$ \\
\hline $\mathrm{FPD} \times \mathrm{F} / \mathrm{CP}$ & I & January & polynomical 2th st. & $y=-6.6196 x^{2}+10.491 x+519.13$ & 0.0179 & 0.13 & $* *$ \\
\hline $\mathrm{FPD} \times \mathrm{F} / \mathrm{CP}$ & I & July & linear & $y=-7.346 x+529.16$ & 0.0215 & -0.15 & $* *$ \\
\hline $\mathrm{FPD} \times \mathrm{F} / \mathrm{CP}$ & I & July & exponential & $y=529.26 e^{-0.0142 x}$ & 0.0218 & 0.15 & $* *$ \\
\hline $\mathrm{FPD} \times \mathrm{FFA}$ & I & November & linear & $y=1.1865 x+525.21$ & 0.0095 & 0.10 & $* *$ \\
\hline $\mathrm{FPD} \times \mathrm{FFA}$ & I & November & polynomical 2th st. & $y=0.5618 x^{2}+0.1705 x+525.45$ & 0.0141 & 0.12 & $* *$ \\
\hline $\mathrm{FPD} \times \mathrm{FFA}$ & I & December & linear & $y=1.3606 x+522.29$ & 0.0127 & 0.11 & $* *$ \\
\hline $\mathrm{FPD} \times \mathrm{FFA}$ & I & December & polynomical 2th st. & $y=0.2155 x^{2}+0.8468 x+522.51$ & 0.0135 & 0.12 & $* *$ \\
\hline $\mathrm{FPD} \times \mathrm{SCC}$ & $\mathrm{I}$ & December & linear & $y=-0.0036 x+524.31$ & 0.0066 & -0.08 & $* *$ \\
\hline
\end{tabular}

$\mathrm{r}=$ coefficient or index of correlation; $\mathrm{R}^{2}=$ coefficient of determination; $* *=\mathrm{P}<0.01$

III: Results of month regression analyse between FPD ( $y$ ) and lactose content $(x)$ in year data file (I)

\begin{tabular}{llccc}
\hline \multicolumn{1}{c}{ Month } & \multicolumn{1}{c}{ Equation } & $\begin{array}{c}\text { Coefficient of } \\
\text { determination }\left(\mathbf{R}^{2}\right)\end{array}$ & $\begin{array}{c}\text { Coefficient or index } \\
\text { of correlation }\end{array}$ & Significance \\
\hline January & $\mathrm{y}=17.35 \mathrm{x}+436.48$ & 0.0799 & 0.2827 & $* * *$ \\
February & $\mathrm{y}=401.78 \mathrm{x}^{0.1641}$ & 0.0809 & 0.2844 & $* * *$ \\
March & $\mathrm{y}=15.83 \mathrm{x}+443.9$ & 0.0900 & 0.3000 & $* * *$ \\
April & $\mathrm{y}=15.363 \mathrm{x}+446.22$ & 0.0749 & 0.2737 & $* * *$ \\
May & $\mathrm{y}=18.951 \mathrm{x}+426.25$ & 0.1068 & 0.3268 & $* * *$ \\
June & $\mathrm{y}=20.707 \mathrm{x}+417.6$ & 0.1197 & 0.3460 & $* * *$ \\
July & $\mathrm{y}=378.79 \mathrm{x}+1982$ & 0.1201 & 0.3466 & $* * *$ \\
August & $\mathrm{y}=19.422 \mathrm{x}+423.3$ & 0.0849 & 0.2914 & $* * *$ \\
September & $\mathrm{y}=16.07 \mathrm{x}+440.46$ & 0.0728 & 0.2698 & $* * *$ \\
October & $\mathrm{y}=14.068 \mathrm{x}+450.88$ & 0.0688 & 0.2623 & $* * *$ \\
November & $\mathrm{y}=14.603 \mathrm{x}+451.99$ & 0.0757 & 0.2751 & $* * *$ \\
December & $\mathrm{y}=15.58 \mathrm{x}+448.03$ & 0.0897 & 0.2995 & $* *$ \\
\hline
\end{tabular}

ns $=$ no significant $\mathrm{P}>0.05 ; *$, ** and $* * *=$ statistically significant $\mathrm{P} \leq 0.05 ; \mathrm{P} \leq 0.01$ and $\mathrm{P}<0.001$

of FPD along crude protein increasing. The more efficient situation was observed logically at the relationships between the FPDs and the lactose contents (Tab. II and III; Fig. 5). Those swaied ( $\left.{ }^{2}\right)$ from 0.0500 in December to 0.1197 in May, which is equal to $0.35(\mathrm{P}<0.001)$ as the correlation coefficient (r). It means that $12 \%$ of the FPD variability is explainable by lactose content variability. The non linear (poweral) relationship was still a little closer (Tab. II and III with correlation index 0.35; $\mathrm{P}<0.001$ ). The FPDs decrease (are improved) regularly with higher lactose contents. Surprisingly, the poor relationships were calculated between month FPDs and total dry matter contents. Those increased from 0.0057 in September up to 0.0167 in January $\left(\mathrm{R}^{2} ; \mathrm{r}=0.13 ; \mathrm{P}<0.01\right.$, Tab. II; the poweral relationship was a little closer only, Tab. II). Despite this result the quite closer month relationships were received between the FPDs and the solid non fat contents. Those ranged from $0.0449(\mathrm{r}=0.21 ; \mathrm{P}<$ 0.001 ) in October to 0.0952 in January (Tab. IV and Fig. 6). The last result is equal to the correlation coefficient 0.31 ( $\mathrm{P}<0.001)$. It means the consistent apparent improvement of the FPDs along the SNF contents increasing, according to the expectation. Our findings about the relationships between the FPD values and the lactose and SNF contents are comparable to our previous results (Macek et al., 2005) and to the results which were published by some other authors (Demott, 1969; Brouwer, 1981; Walstra and Jenness, 1984; Koops et al., 1989; Buchberger and Klostermeyer, 1995; Buchberger, 1994; 1997; Crombrugge, 2003; Chládek and Čejna, 2005), as well. On the contrary, the relationships 
IV: Results of he month regression analyse between FPD $(y)$ and SNF content $(x)$ in year data file (I)

\begin{tabular}{llccc}
\hline \multicolumn{1}{c}{ Month } & \multicolumn{1}{c}{ Equation } & $\begin{array}{c}\text { Coefficient of } \\
\text { determination }\left(\mathbf{R}^{2}\right)\end{array}$ & $\begin{array}{c}\text { Coefficient or index } \\
\text { of correlation }\end{array}$ & Significance \\
\hline January & $\mathrm{y}=7.2037 \mathrm{x}+457.87$ & 0.0952 & 0.3085 & $* * *$ \\
February & $\mathrm{y}=398.73 \mathrm{x}$ 0.1232 & 0.0964 & 0.3105 & $* * *$ \\
March & $\mathrm{y}=5.4036 \mathrm{x}+474.22$ & 0.0726 & 0.2694 & $* * *$ \\
April & $\mathrm{y}=5.8035 \mathrm{x}+471.23$ & 0.7170 & 0.8468 & $* * *$ \\
May & $\mathrm{y}=6.1564 \mathrm{x}+466.35$ & 0.0936 & 0.3059 & $* * *$ \\
June & $\mathrm{y}=6.5944 \mathrm{x}+462.93$ & 0.0864 & 0.2939 & $* * *$ \\
July & $\mathrm{y}=7.9249 \mathrm{x}+451.15$ & 0.0935 & 0.3058 & $* * *$ \\
August & $\mathrm{y}=6.6524 \mathrm{x}+462.38$ & 0.0812 & 0.2850 & $* * *$ \\
September & $\mathrm{y}=5.7384 \mathrm{x}+470.69$ & 0.0685 & 0.2617 & $* *$ \\
October & $\mathrm{y}=6.16 \mathrm{x}+469.09$ & 0.0716 & 0.2676 & $* .2119$ \\
November & $\mathrm{y}=4.8065 \mathrm{x}+480.97$ & 0.0449 & 0.2276 & $* *$ \\
December & $\mathrm{y}=5.0558 \mathrm{x}+479.54$ & 0.0518 & 0.2476 & $* * *$ \\
\hline
\end{tabular}

$$
\begin{array}{lll}
y=398.73 x^{0.1232} & \text { SNF versus FPD } & y=7.2037 x+457.87 \\
R^{2}=0.0964 & & R^{2}=0.0952
\end{array}
$$

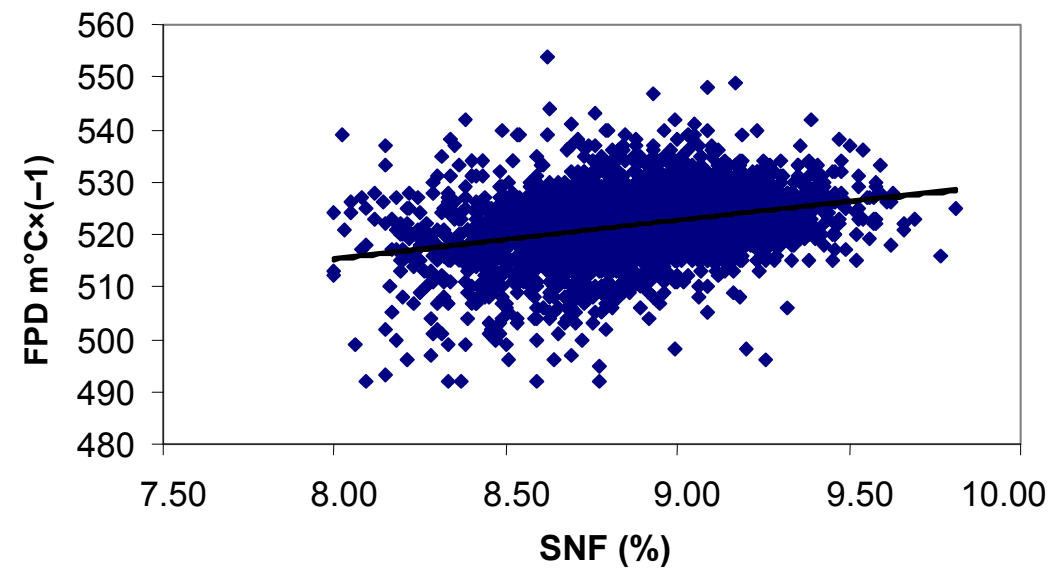

5: The relationship between FPD and SNF in whole (I, validated data set) set in January linear $\mathrm{r}=0.31^{* * *}$

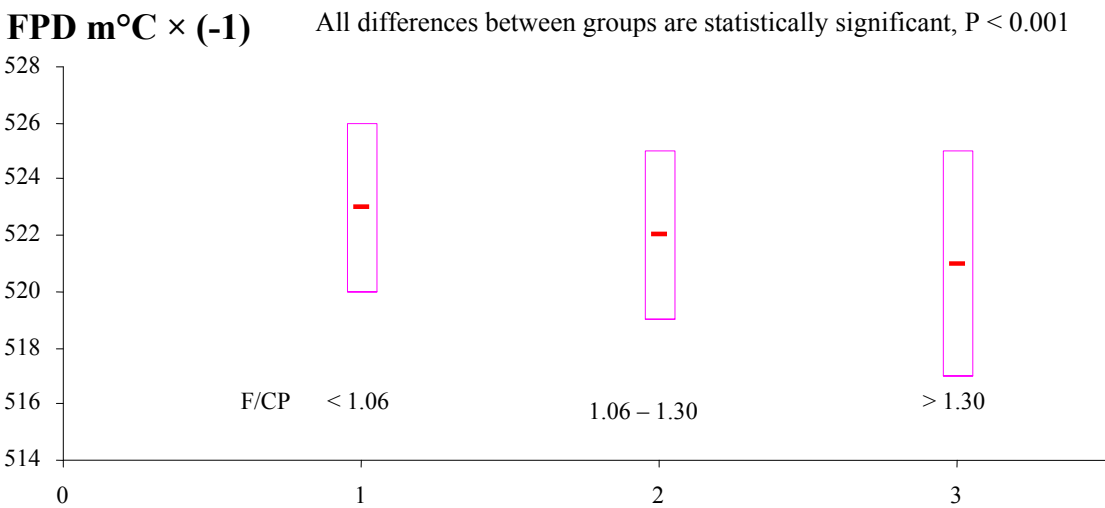

6: The box graph about the influence of milk F/CP ratio as an indicator of the energy metabolism of the dairy cow herds on the raw cow milk freezing point depression (FPD) in the bulk samples

Ranked by presupposed energy metabolism of the dairy cows where the F/CP groups: $<1.06=$ the shortage of the structural fiber in the feeding ration; $1.06-1.30=$ in order; $>1.30$ $=$ the shortage of dairy herd energy maintenance, a risk of ketosis occurrence. 


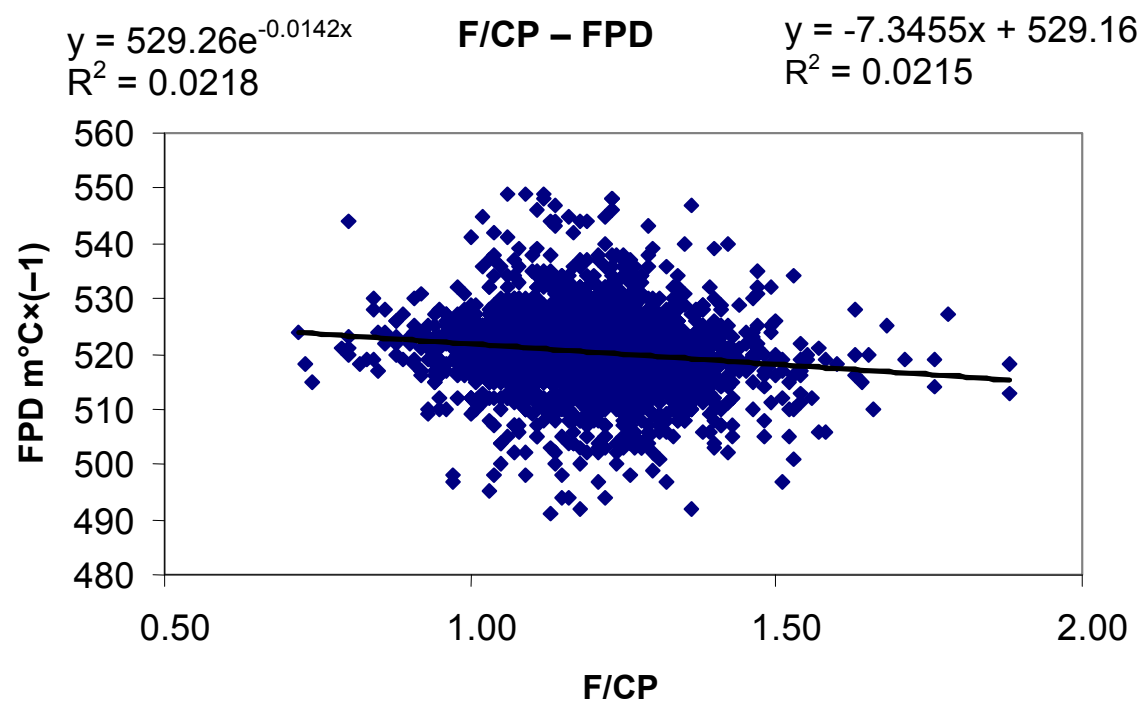

7: The relationship between FPD and F/CP ratio in whole validated data set (I) in July Set I: July

linear $\mathrm{r}=-0.15^{*}$

$\begin{array}{ll}y=502.01 x^{0.0424} & \text { Casein versus FPD } \begin{array}{l}y=8.7437 x+500.03 \\ R^{2}=0.0558\end{array} \\ R^{2}=0.0542\end{array}$

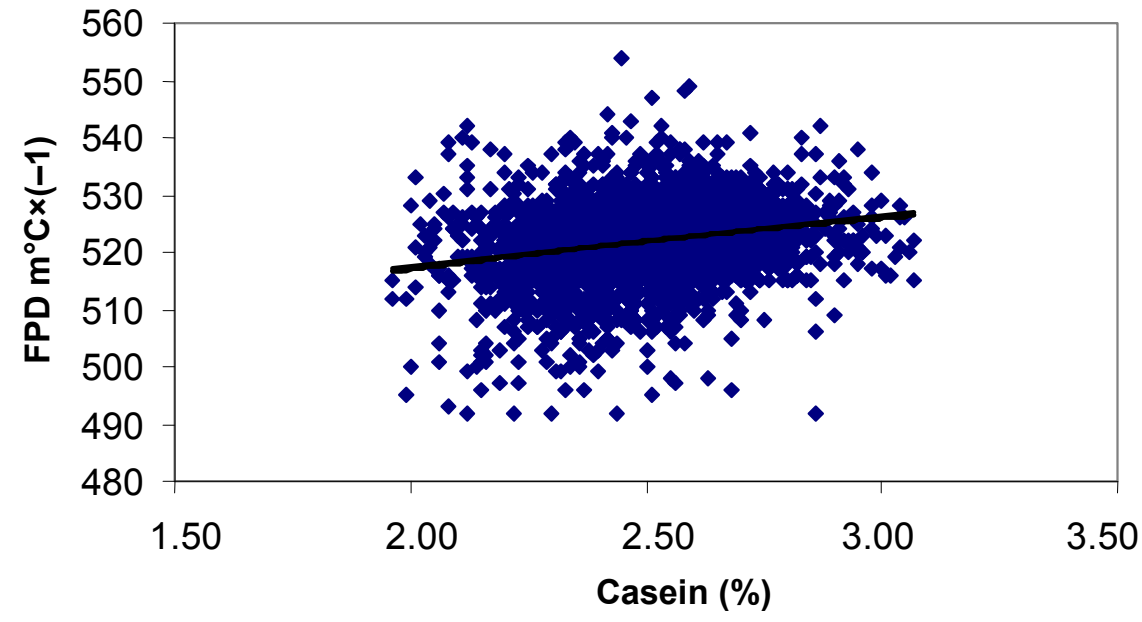

8: The relationship between FPD and casein content in whole (I, validated data set) set in January linear $\mathrm{r}=0.23^{* *}$

between the FPDs and F/CP ratios were poor. Determination coefficients ranged from 0.0059 in October up to 0.0215 in July, which is equal to -0.15 (r; P $<0.01$; linear equation, Tab. II, Fig. 7). The non linear relationships show (as for instance in January, Tab. II, Fig. 7) the higher (worse) FPDs for low and high F/CP ratios. It could cohere with poorer or imbalanced nourishments of dairy cow herds. The problem will be discussed below once more. On the contrary again, the month relationships between the FPDs and the casein contents were closer. Those varied from $0.0157(\mathrm{r}=0.13 ; \mathrm{P}<0.01)$ in October to $0.0542(\mathrm{r}=0.23 ; \mathrm{P}<0.001$; Fig. 8$)$ in January and this fact indicates, that $5.4 \%$ of variation in the FPD is explained by variation in the casein content as maximum. The casein content increasing influences the FPD towards its improvement. The non linear regression equation (exponential) of this relationship was $\mathrm{y}=502.01 \mathrm{x}^{0.0424}(\mathrm{r}=0.24 ; \mathrm{P}<0.001$; Fig. 8). The dependence of the FPD on urea concentration was a little closer and ranked between $0.0241(\mathrm{r}=0.16 ; \mathrm{P}<0.001)$ in October and 0.0687 $(\mathrm{r}=0.26 ; \mathrm{P}<0.001 ;$ Tab. V and Fig. 9$)$ in March. The milk urea concentration enhancement improves the FPD value according to expectation. These our new results are in accordance with our previous find (Macek et al., 2005) in terms of tendency and with discoveries and opinions of other authors (Walstra 


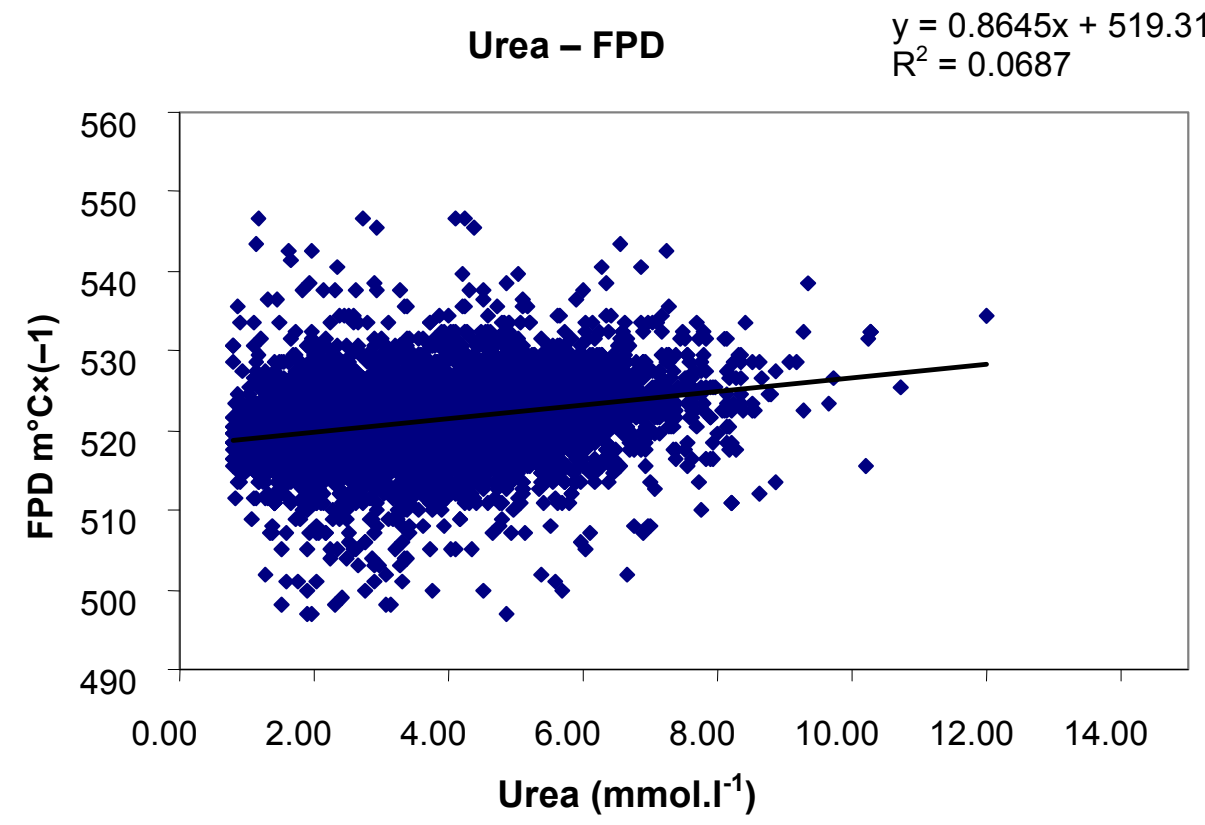

9: The relationship between FPD and milk urea concentration in whole (I, validated data set) set in March $\mathrm{r}=0.26^{* *}$

V: Results of month regression analyse between FPD $(y)$ and milk urea concentration $(x)$ in year data file (I)

\begin{tabular}{llccc}
\hline \multicolumn{1}{c}{ Month } & \multicolumn{1}{c}{ Equation } & $\begin{array}{c}\text { Coefficient of } \\
\text { determination }\left(\mathbf{R}^{2}\right)\end{array}$ & $\begin{array}{c}\text { Coefficient or index } \\
\text { of correlation }\end{array}$ & Significance \\
\hline January & $\mathrm{y}=1.1074 \mathrm{x}+518.35$ & 0.0651 & 0.2551 & $* * *$ \\
February & $\mathrm{y}=0.8297 \mathrm{x}+519.27$ & 0.0527 & 0.2296 & $* *$ \\
March & $\mathrm{y}=0.8645 \mathrm{x}+519.31$ & 0.0687 & 0.2621 & $* * *$ \\
April & $\mathrm{y}=0.8516 \mathrm{x}+517.34$ & 0.0576 & 0.2400 & $* *$ \\
May & $\mathrm{y}=0.6009 \mathrm{x}+518.51$ & 0.0324 & 0.1800 & $* *$ \\
June & $\mathrm{y}=0.8808 \mathrm{x}+516.97$ & 0.0430 & 0.2074 & $* *$ \\
July & $\mathrm{y}=0.6772 \mathrm{x}+517.66$ & 0.0283 & 0.1682 & $* *$ \\
August & $\mathrm{y}=0.6851 \mathrm{x}+517.74$ & 0.0319 & 0.1786 & $* *$ \\
September & $\mathrm{y}=0.9062 \mathrm{x}+519.78$ & 0.0570 & 0.2387 & $* *$ \\
October & $\mathrm{y}=0.6412 \mathrm{x}+521.62$ & 0.0241 & 0.1552 & $* *$ \\
November & $\mathrm{y}=0.871 \mathrm{x}+522.92$ & 0.0369 & 0.1921 & $* .2124$ \\
December & $\mathrm{y}=0.8962 \mathrm{x}+520.17$ & 0.0451 & & $*$ \\
\hline
\end{tabular}

and Jenness, 1984; Buchberger, 1997; Kirchnerová and Foltys, 2005; Chládek and Čejna, 2005; Kirchnerová et al., 2009), too. The dependence of the FPD on free fatty acid concentration in milk was quite low and varied from $0.0095(\mathrm{r}=0.10 ; \mathrm{P}<0.01)$ in November up to 0.0127 ( $\mathrm{r}=0.11$; $\mathrm{P}<0.01$; Tab. II) in December. The closes relationship was noted with the non linear regression equation $(\mathrm{r}=0.12$; $\mathrm{P}<0.01$; Tab. II). The FPD was very slowly reduced (improved) due to higher FFA concentration. The relationship between FPD and SCC was very poor and ranked between zero in June includig log transformed values of SCC and $0.0066(\mathrm{r}=-0.08$; $\mathrm{P}<0.01$; Tab. II) only in December, although SCC is correlated usually with lactose content (Hanuš et al., 1992), which is normally correlated to FPD. This find is a little different from our previous result (Macek et al., 2005) or from the result of authors Chládek and Čejna (2005). Nevertheless the influence of the SCC on the FPD was noted as very poor in the bulk milk samples under the raw milk quality conditions in the Czech Republic.

Milk freezing point and balance in presupposed state of dairy cow herd nutrition in terms of nitrogen matter/energy ratio

The presupposed nutrition state of dairy cow herds (bulk milk samples) in terms of nitrogen matters/energy balance in relationship to their milk yield was estimated according to combinations of urea and crude protein contents in milk. This was classified according to Tab. VI. Nine nutritional 
VI: The grouping of milk samples in accordance with presupposed dairy cow nutrition balance (nitrogen matters/energy, N/E) according to milk protein and urea contents (system is adjusted according to Kirchgessner et al., 1985, 1986)

\begin{tabular}{|c|c|c|c|c|}
\hline \multirow{2}{*}{\multicolumn{2}{|c|}{ Milk }} & \multicolumn{3}{|c|}{ Protein \% } \\
\hline & & $<3.10$ & $3.10-3.50$ & $>3.50$ \\
\hline \multirow{9}{*}{ Urea mmol.1.1 } & \multirow[b]{3}{*}{$<3.33$} & 1 & 2 & 3 \\
\hline & & $\mathrm{N}-\mathrm{E}-$ & $\mathrm{N}-\mathrm{E} 0$ & $\mathrm{~N}-\mathrm{E}+$ \\
\hline & & $\begin{array}{c}\mathrm{n}=2696 \\
\text { FPD }-0.51855 \pm 0.007288 \\
\mathrm{vx}=1.4 \%\end{array}$ & $\begin{array}{c}\mathrm{n}=2242 \\
\text { FPD }-0.51978 \pm 0.006137 \\
\mathrm{vx}=1.2 \%\end{array}$ & $\begin{array}{c}\mathrm{n}=349 \\
\text { FPD }-0.52140 \pm 0.005674 \\
\mathrm{vx}=1.1 \%\end{array}$ \\
\hline & \multirow[b]{3}{*}{$3.33-5.80$} & 4 & 5 & 6 \\
\hline & & NOE- & NOE 0 & $\mathrm{NOE}+$ \\
\hline & & $\begin{array}{c}\mathrm{n}=16083 \\
\text { FPD }-0.52090 \pm 0.005874 \\
\mathrm{vX}=1.1 \%\end{array}$ & $\begin{array}{c}\mathrm{n}=26867 \\
\mathrm{FPD}-0.52228 \pm 0.004840 \\
\mathrm{vx}=0.9 \%\end{array}$ & $\begin{array}{c}\mathrm{n}=4621 \\
\text { FPD }-0.52363 \pm 0.004818 \\
\mathrm{vX}=0.9 \%\end{array}$ \\
\hline & \multirow[b]{3}{*}{$>5.80$} & 7 & 8 & 9 \\
\hline & & $\mathrm{N}+\mathrm{E}-$ & $\mathrm{N}+\mathrm{E} 0$ & $\mathrm{~N}+\mathrm{E}+$ \\
\hline & & $\begin{array}{c}\mathrm{n}=5540 \\
\text { FPD }-0.52326 \pm 0.005833 \\
\mathrm{vX}=1.1 \%\end{array}$ & $\begin{array}{c}\mathrm{n}=9407 \\
\text { FPD }-0.52432 \pm 0.004876 \\
\mathrm{vX}=0.9 \%\end{array}$ & $\begin{array}{c}\mathrm{n}=1743 \\
\text { FPD }-0.52536 \pm 0.004785 \\
\mathrm{vX}=0.9 \%\end{array}$ \\
\hline
\end{tabular}

$\mathrm{n}=$ number of cases; $\mathrm{vx}=$ variation coefficient; milk freezing point depression (FPD) in ${ }^{\circ} \mathrm{C} ; \mathrm{N}=$ nitrogen matter dairy cow (herd) maintenance; E = energy maintenance; + = surplus; 0 = balanced; - = insufficiency

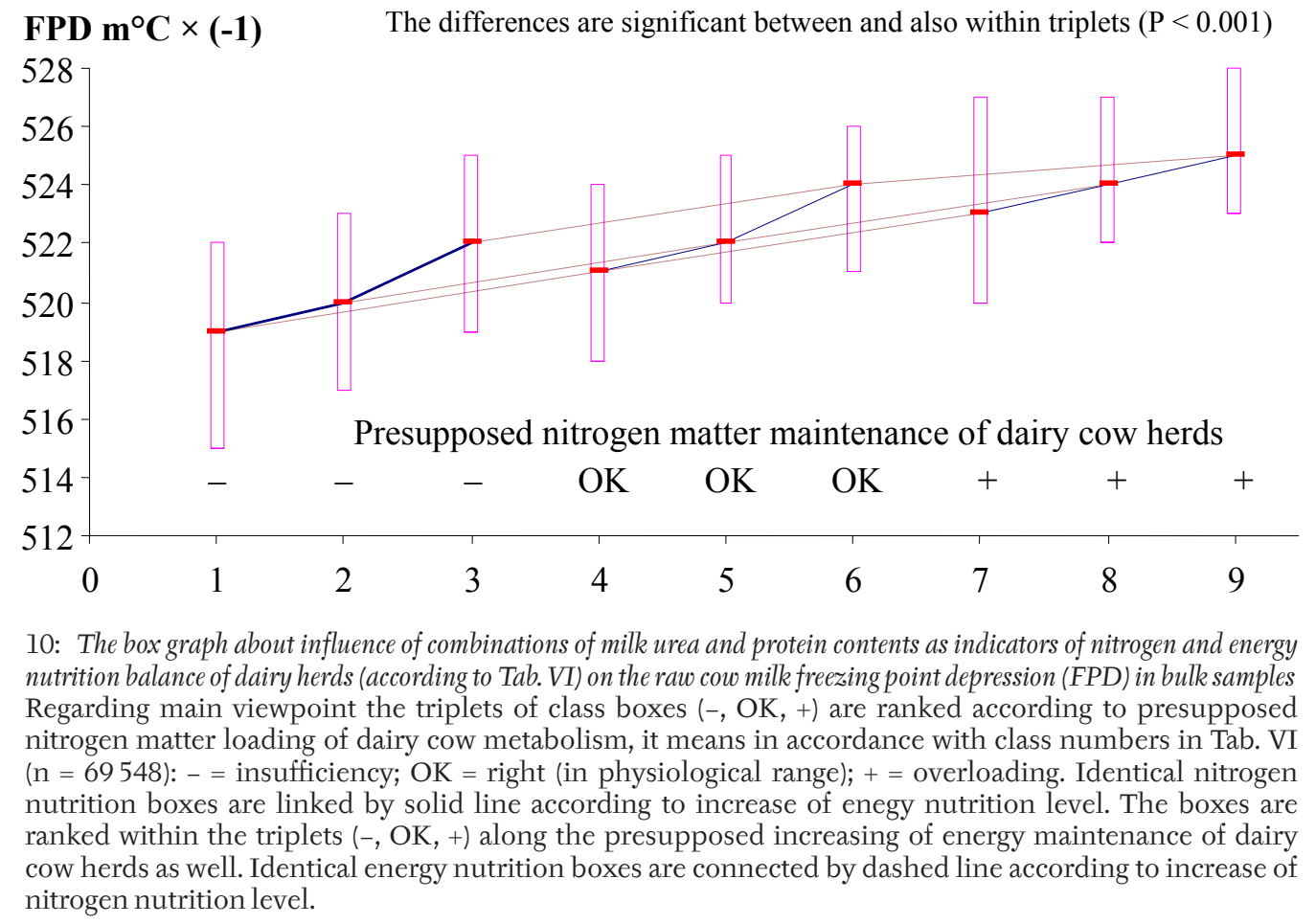

groups of milk samples were obtained. The milk urea and protein physiological ranges were adjusted according to mentioned literature references. The average EPDs, which were relevant to created classes, are shown in the table as well. FPD values of this groups were tested in consideration of significance of their mutual differences by the t-test. Results are shown by the box graphs in Fig. 10. These are grouped according to nitrogen matter maintenance in the first viewpoint $(-, \mathrm{OK},+)$. The highest (the worst) FPD average was stated in the group 1 with presupposed nitrogen matter and energy insufficiency $\left(-0.51855 \pm 0.007288^{\circ} \mathrm{C}\right.$; Tab. VI). The lowest (the best) FPD was foud in the group 9 with presupposed nitrogen matter and energy surplus in the feeding ration $\left(-0.52536 \pm 0.004785^{\circ} \mathrm{C}\right)$. The FPD difference between these two groups was statistically significant $(t=34.5$ and $\mathrm{P}<0.001)$. It is clear that this estimated phenomenon is linked directly with protein and urea contents in milk. 
FPD $\mathbf{m}^{\circ} \mathbf{C} \times \mathbf{( - 1 )} \quad$ All differences between seasonal periods are statistically significant, $\mathrm{P}<0.001$

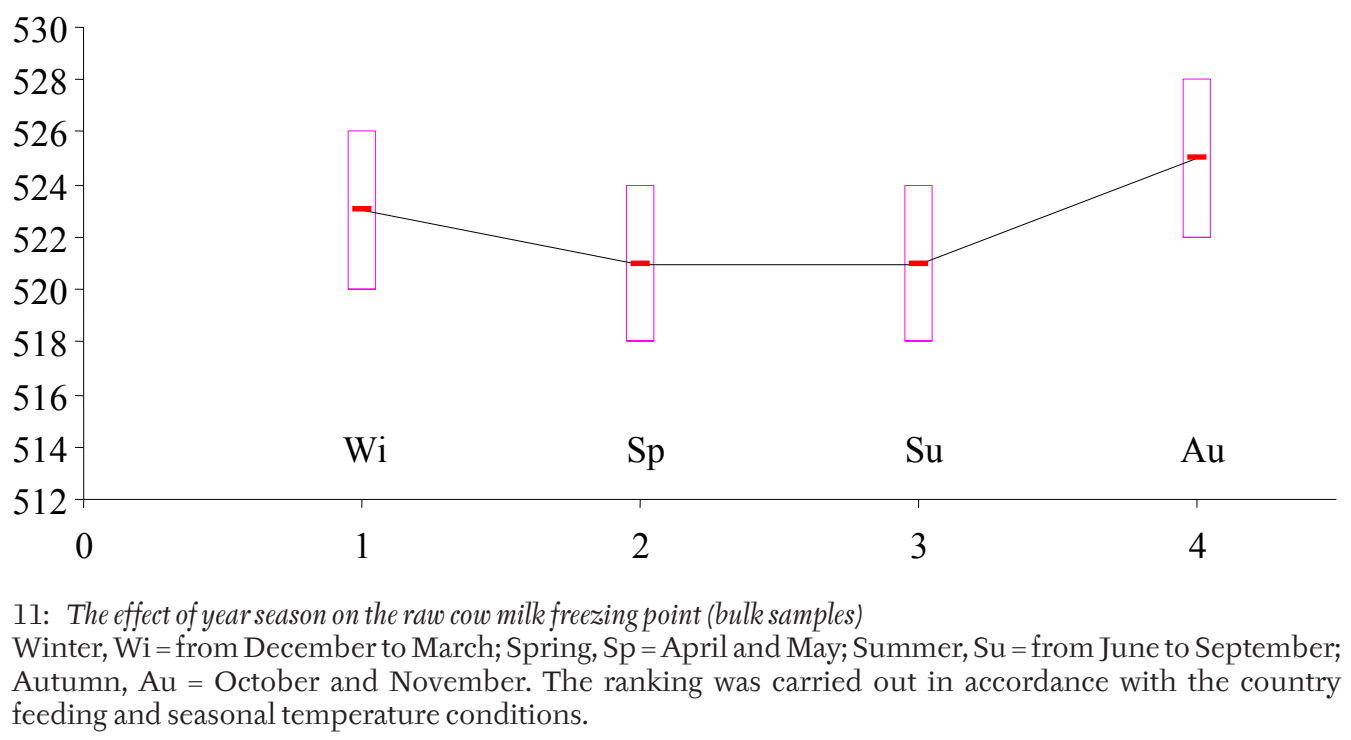

Nevertheless, this shows indirectly on relevancy of dairy cow nourishment in terms of occurrence of FPD defects and their prevention, too. There are 36 pair combinations differences between nine nutrition groups. All these differences were tested. Most of them were significant $(35=97.2 \%$; $<0.001$ ). Only one difference was no significant $(3-4$; $P>0.05)$. The FPD values were significantly lower (better) in the case of higher likelihood for higher nitrogen matter loading of dairy cows due to their nourishment (Fig. 10 and Tab. VI; $\mathrm{P}<0.001$ ). Within all three triplets $(1,2,3 ; 4,5,6 ; 7,8,9)$ the same trend was reinforced by increased probability for higher energy maintenance of dairy herds ( $P<0.001$ ). The mentioned tendencies are linked with higher milk urea concentrations, as it has been already introduced above. This second tendency is a little different from our results in another paper (Macek et al., 2005) where such trend was not observed. The nutrition class effect of dairy herds in terms of probability for nitrogen matter/energy balance of dairy cows on FPD was exhibited as highly significant $(\mathrm{P}<0.001)$ according to our results. These our presented results are similar to those which were described previously by Buchberger (1997) in the main trends. Also according to the results of MP Bayern (1993, 1994 and 1995) a conclusion was estimated that FPD defects had been caused due to poor dairy cow nourishment in 50.2 and 58.8\% of cases while due to extraneous water addition it was caused only by 34.5 and $41.2 \%$ of cases in the practice.

\section{Milk freezing point and presupposed energy nourishment of dairy cow herds}

Milk fat and F/CP ratio are good indicators of dairy cow energy balance during the lactation, especially in its first third (Agabriel et al., 1991; Bíro et al., 1992; Geishauser and Ziebell, 1995; Schulz, 1997; Illek and Pechová, 1997; Pechová et al., 2000; Gasteiner, 2000, 2003). A higher F/CP value demonstrates an energy deficiency (ketosis risk) and lower value shows on deficiency of structural fibre in dairy cow nourishment. F/CP ratio, which ranked according to Tab. II was related to FPD. This is demonstrated in Fig. 11. The FPDs were significantly higher (worse) in the case of a suspicion on the energy deficiency and the risk of ketosis as compared to the presumption for normal balanced nourishment of dairy herds (Fig. 11; $-0.52105 \pm 0.006436{ }^{\circ} \mathrm{C}>-0.52244 \pm$ $\left.0.005367^{\circ} \mathrm{C} ; \mathrm{t}=22.3 ; \mathrm{P}<0.001\right)$. On the other hand surprisingly, the FPDs were lower (better) in the case of a suspicion on the the shortage of the structural fiber in the feeding ration in comparison to the presumption for normal balanced nourishment of the dairy cow herds (Fig. 11; -0.52291 \pm $0.005469{ }^{\circ} \mathrm{C}<-0.52244 \pm 0.005367{ }^{\circ} \mathrm{C} ; \mathrm{t}=5.9$; $\mathrm{P}<0.001)$. Nevertheless, the difference and $t-v a l u e$ are evidently lower than in the previous case. The FPD was improved by normal or lower value of F/ $\mathrm{CP}$ ratio which is different result as compared to our previous finding (Macek et al., 2005). However, this result is more probable in terms of the right interpretation of the possible mistakes in the dairy cow herd nourishment because of larger data set.

\section{CONCLUSION}

This is very well known that there are sure problems to meet the legislative discrimination limit value of raw milk freezing point $\left(\leq-0.520{ }^{\circ} \mathrm{C}\right)$ for part of dairy herds, especially with high milk yield or in less favourable areas of the country where the sources for adequate dairy cow nutrition are poorer or too expensive. It means not for extraneous water addition as technological lack of discipline but for other physiological or sometimes pathological reasons. That is reason why this is important to 
define a new real FPD legislative discrimination limit in right way for specific country conditions. This is important to explain all effects on FPD as far as possible. Results published in this paper about FPD variability sources are interesting for improvement of mentioned explanations and estimations.

\section{SUMMARY}

The milk freezing point depression (FPD) is very important physical property. FPD is influenced by milk composition, especially by components, which are connected with osmotic pressure and by other physiological factors as well. Under sure conditions this is possible to indicate a foreign (extraneous) water addition into milk according to FPD value. Therefore FPD is used to raw milk quality control in the framework of milk food chain quality assurance generally. This is necessary to have a good estimated legislative FPD discrimination limit for such purpose of milk quality control. This paper was aimed at obtaining information for possibility to improve mentioned estimation with taking of real biotic FPD variability sources in the country into account. There is necessary at derivation of milk FPD discrimination limit to take various factors into account as (in groups): 1) season variations; estimated state of dairy cow nutrition (in terms of the nitrogen/energy balance by milk urea and protein content combinations or by fat/crude protein ratio); cattle breed ratio; milk yield of dairy cows; 2) possible foreign (extraneous) water addition (technologically unavoidable water - for instance condensing water - as technical effect of machine milking); pasteurization; carbon dioxide and water steam evaporation under technological conditions; technological fat content manipulation (Hanuš et al., 2010, 2011 a, b); 3) some milk components and properties (such as true and whey protein, somatic cell count, urea and citric acid content or value of titration acidity); 4) other country conditions. Impacts some of mentioned factors on milk FPD and their relations to FPD are quantified in this paper. A large data set was evaluated ( $\mathrm{n}=$ from 11540 to 72607 bulk raw cow milk samples). Althouhg the frequency distributions of FPD month data sets were different from normal model (but first of all for high number of cases) the differences were lower in more important obliqueness. Therefore conventional statistic was suitable method for evaluation. Regarding seasonal effect on FPD the highest (the worst) value was in Spring $\left(-0.52097 \pm 0.004877^{\circ} \mathrm{C}\right.$; variation $\left.0.9 \%\right)$. The lowest (the best) FPD was in Autumn (-0.52516 $\pm 0.005725^{\circ} \mathrm{C}$; 1.1\%). This difference was significant $(\mathrm{P}<0.001)$. It could be probably influenced by nutrition and temperature effect variations, despite using of total mixed ration on the basis of preserved fodder feedstuffs for nourishment of dairy cow herds during whole year. The month relationships between FPD and fat content were practically almost independent. More relevant relationships (determination $\mathrm{R}^{2}$ ) were stated between FPDs and crude protein contents, 0.0408 in January (correlation 0.20; $\mathrm{P}<0.001$ ). It means slow consistent improvement of FPD along crude protein increasing. More efficient situation was observed between FPDs and the lactose contents. $\mathrm{R}^{2}$ was 0.1197 in May (r 0.35; P $\left.<0.001\right)$. It means that $12 \%$ of FPD variability is explainable by lactose content variability. FPDs decrease (are improved) regularly with higher lactose contents. Relationship between FPD and solid non fat content increased to $\mathrm{r} 0.31$ $(\mathrm{P}<0.001)$. Relationship between FPD and F/CP (fat/crude protein) ratio was poorer. $\mathrm{R}^{2}$ increased to 0.0215 in July $(\mathrm{r}-0.15 ; \mathrm{P}<0.01)$. Month relationships between FPDs and casein contents were closer ( $\mathrm{r}$ increased to 0.23 ( $\mathrm{P}<0.001$ ) in January). 5.4\% of FPD variations are explained by variation in casein content. The dependence of FPD on urea concentration (U) was also closer and ranked to r 0.26 ( $\mathrm{P}<0.001)$ in March. The milk U enhancement improves FPD value. The dependence of FPD on free fatty acid concentration in milk was quite low. The relationship between FPD and somatic cell count was poor. The presupposed nutrition state of dairy herds in terms of nitrogen matters/energy balance was estimated according to combinations of urea and crude protein contents in milk. The worst FPD average was in group with presupposed nitrogen matter and energy insufficiency (-0.51855 $\left.\pm 0.007288^{\circ} \mathrm{C}\right)$. The best FPD was in group with presupposed nitrogen matter and energy surplus in feeding ration $\left(-0.52536 \pm 0.004785^{\circ} \mathrm{C}\right)$. Difference was significant $(\mathrm{P}<0.001)$. FPDs were significantly worse in the case of a suspicion on the energy deficiency and the risk of ketosis (on the basis of fat/ crude protein ratio) as compared to the presumption for normal balanced energy nourishment of dairy herds $\left(-0.52105 \pm 0.006436^{\circ} \mathrm{C}>-0.52244 \pm 0.005367^{\circ} \mathrm{C} ; \mathrm{P}<0.001\right)$. This is important to estimate a new real FPD legislative discrimination limit and its inherent variation according to biotic factors in right way for specific country conditions to possibility of better added water identification. Results published in this paper about FPD variability sources are interesting for improvement of such estimation.

This paper was supported by projects KONTAKT ME 09081, MSM 2678846201 and MSM 2672286101 and by NRL-RM activities and education project MSMT-CZ.1.07/2.3.00/09.0081. 


\section{REFERENCES}

AGABRIEL, C., COULON, J. B., MARTHY, G., 1991: Facteurs de variations du rapport des teneurs en matiéres grasses et protéiques du lait de vache. INRA Product. Anim., 4, 2, 141-149.

BAUCH, W., HUBER, B., BUCHBERGER, J., 1993: Zum Einfluss einiger Parameter auf die Bestimmung des Gefrierpunktes von Milk mit den Cryostar II - LC. DMZ, Lebensmittel und Milchwirtschaft, 114, 5, 112-114.

BÍRO, D., LABUDA, J., CABADAJOVÁ, M., 1992: Factors influencing cow milk production and fat to protein content ratio. (In Slovak) Živoč. Výr., 37, 6-7, 521-528.

BOSSUYT, R., 2003: Milk quality payment in Belgium: why and how. AFEMA Tagung, Mosonmagyaróvár, May.

BROUWER, T., 1981: Calculations concerning the determination of the freezing-point depression of milk. Neth. Milk Dairy J., 35.

BUCHBERGER, J., KLOSTERMEYER, H., 1995: Determination of freezing point in milk with the „System 4000 Milko-Scan” from Foss Electric A/S. DMZ, 23/24, 1-14.

BUCHBERGER, J., 1990a: Einfluss von Rasse, Laktationsstadium und Untersuchungsfehler auf den Gefrierpunkt der Milch. Schule und Beratung, 11/90, IV-9-11.

BUCHBERGER, J., 1997: Erfahrungen mit der Gefrierpunktuntersuchung der Milch. Sborník VÚCHS Rapotín „Management chovu dojnic”, duben.

BUCHBERGER, J., 1991: Probleme auch ohne Fremdwasser? Top Agrar, 2, R24-R26.

BUCHBERGER, J., 1990b: Ursachen von Überschreitungen des Grenzwertes von -0,515 ${ }^{\circ} \mathrm{C}$ beim Gefrierpunkt der Milch. Schule und Beratung, 9-10, 1990 b, IV-8-10.

BUCHBERGER, J., 1994: Zum Gefrierpunkt der Milch: Bewertung und Interpretation. DMZ, 115, 8, 376-383.

CROMBRUGGE VAN, J. M., 2003: Freezing Point. Bulletin of IDF, 383, 15-22.

ČSN EN ISO 13366-3, 1998: Milk - Enumeration of somatic cells - Part 3: Fluoro-opto-electronic method. (In Czech) Český normalizační institut, Praha.

ČSN 57 0536, 1999: Determination of milk composition by mid-infrared analyzer. (In Czech) Český normalizační institut, Praha.

ČSN 57 0530, 1973: Methods for testing of milk and milk products. Vydavatelství úřadu pro normalizaci a měření, Praha.

ČSN 57 0529, 1993: Raw cow milk for dairy factory treatment and processing. Praha, ČNI.

ČSN 57 0538, 1998: Determination of freezing point in milk - cryoscope method. Czech Office for normalization and measurement, Prague.

DEMOTT, B. J., 1969: Relationship of freezing point of milk to its specific gravity and concentration of lactose and choride. J. Dairy Sci., 52, 6, 882.
EEC 92/46, 1992: Council Directive: Milk and milk product quality. Official Journal, L 268, 14/9/1992, $1-32$.

EISSES, J., ZEE, B., 1980: The freezing point of autentic cow's milk and farm tank milk in the Netherlands. Neth. Milk Dairy J., 34, 162-180.

FREEMAN, T. R., BUCY, J. L., 1967: Distribution of milk freezing points in authentic herd samples. J. Dairy Sci., 50, 6, 951.

GASTEINER, J., 2000: Ketose, die bedeutendste Stoffwechselerkrankung der Milchkuh. In: BAL Gumpenstein Bericht, 27. Viehwirtschaftliche Fachtagung, Juni, 11-18.

GASTEINER, J., 2003: Der Einsatz glukoplastischer Verbindungen in der Milchviehfütterung. In: BAL Gumpenstein Bericht, 30. Viehwirtschaftliche Fachtagung, April, 61-63.

GEISHAUSER, T., ZIEBELL, K. L., 1995: Fett/ Eiweiss-Quotient in der Milch von Rinderherden mit Vorkommen von Labmagenverlagerungen. Dtsch. Tierärztl. Wschr., 102, 469-494.

GENČUROVÁ, V., HANUŠ, O., VYLETĚLOVÁ, M., LANDOVÁ, H., JEDELSKÁ, R., 2008: The relationships between goat and cow milk freezing point, milk composition and properties. Sci. Agric. Boh., 39, 4, 324-328.

HANUŠ, O., BJELKA, M., HERING, P., KLIMEŠ, M., KOZÁKOVÁ, A., PODMOLÍKOVÁ, M., GENČUROVÁ, V., 2003a: Breeding and technological aspects of milk freezing point and prevention of incidental problems. (In Czech) Proceedings of seminar contributions of VÚCHS Rapotín: Breeding and technological aspects of milked cow rearing and milk quality, 81-97.

HANUŠ, O., FRELICH, J., TOMÁŠKA, M., VYLETĚLOVÁ, M., GENČUROVÁ, V., KUČERA, J., TŘINÁCTÝ, J., 2010: The analysis of relationships between chemical composition, physical, technological and health indicators and freezing point in raw cow milk. Czech J. Anim. Sci., 55, 1, ISSN 1212-1819, 11-29.

HANUŠ, O., GENČUROVÁ, V., KUČERA, J., VYLETĚLOVÁ, M., TŘINÁCTÝ, J., 2009: Analyse of relationships between freezing point and selected indicators of udder health state among cow, goat and sheep milk. Acta univ. agric. et silvic. Mendel. Brun., ISSN 1211-8516, LVII, 5, 103-110.

HANUŠ, O., HANUŠOVÁ, K., VYLETĚLOVÁ, M., KOPEC, T., JANU゚, L., KOPECKÝ, J., 2011 a: Selected abiotic factors influencing raw cow milk freezing point depression. Acta Vet. Brno, in opponent procedure.

HANUŠ, O., KLIMEŠ, M., MIHULA, P., KOZÁKOVÁ, A., JEDELSKÁ, R., 2003 b: Impacts of the sampling of milk and the basic milk treatment on its freezing point and other compositional parameters. (In Czech) Výzkum v chovu skotu, XLV, 164, 4, 10-17.

HANUŠ, O., VYLETĚLOVÁ, M., TOMÁŠKA, M., SAMKOVÁ, E., GENČUROVĀ, V., JEDELSKÁ, R., KOPECKÝ, J., 2011 b: The effects of sample fat value manipulation on raw cow milk composition 
and indicators. Acta univ. agric. et silvic. Mendel. Brun., ISSN 1211-8516, LIX, 1, 2011, 101-112.

CHLÁDEK, G., ČEJNA, V., 2005: The relationships between freezing point of milk and milk components and their changes during lactation in Czech Pied and Holstein cows. (In Czech) Acta univ. agric. et silvic. Mendel. Brun., LIII, 5, 63-70.

ILLEK, J., PECHOVÁ, A., 1997: The dairy cow metabolism disorders and milk quality. (In Czech) Farmář, 6, 29-30.

ISO 5764:2002(E), IDF 108:2002(E) 2002: International standard. Milk - Determination of freezing point - Thermistor cryoscope method (Reference method) 15.

JANŠTOVÁ, B., DRAČKOVÁ, M., NAVRÁTILOVÁ, P., HADRA, L., VORLOVÁ, L., 2007: Freezing point of raw and heat-treated goat milk. Czech J. Anim. Sci., 52, 11, 394-398.

JÍLEK, F., ŘEHÁK, D., VOLEK, J., ŠTÍPKOVÁ, M., NĚMCOVÁ, E., FIEDLEROVÁ, M., RAJMON, R., ŠVESTKOVÁ, D., 2006: Effect of herd, parity, stage of lactation and milk yield on urea concentration in milk. Czech J. Anim. Sci., 51, 12, 510-517.

KIRCHGESSNER, M., KREUZER, M., ROTH, MAIER, DORA, A., 1986: Milk urea and protein content to diagnose energy and protein malnutrition of dairy cows. Arch. Anim. Nutr., 36, 192-197.

KIRCHGESSNER, M., ROTH, MAIER, DORA, A., RÖHRMOSER, G., 1985: Harnstoffgehalt in Milch von Kühen mit Energie- bzw. Proteinmangel und anschliessender Realimentation. Z. Tierphysiol. Tiernähr. Futterm. Kde., 53, 264-270.

KIRCHNEROVÁ, K., FOLTYS, V., 2005: The biochemical parameters of milk quality in relationship to freezing point. (In Slovak) Sborník: XXXII. Seminář o jakosti potravin a potravinových surovin. Brno MZLU, 17.

KIRCHNEROVÁ, K., PEŠKOVIČOVÁ, D., FOLTYS, V., 2009: Statistical analysis of unsatisfactory milk freezing point using method of main components. (In Slovak) Sborník: XXXV. Seminář o jakosti potravin a potravinových surovin. ISBN 978-807375-281-1, Brno MZLU, 112-119.

KLÍČNÍK, V., 1978: The technology of the animal products (Dairying). (In Czech) SPN, VŠZ Brno, 270.

KOLOŠTA, M., 2003: Effect of pasture dairy cow nourishment level on the milk freezing point. (In Slovak) Mliekarstvo, 34, 3, 25-27.

KOOPS, J., KERKHOF MOGOT, M. F., VAN HEMERT, H., 1989: Routine testing of farm tank milk by infra-red analysis. IV Prediction of the freezing-point depression from infra-red measurements and conductivity. Neth. Milk Dairy J., 43, 3-16.

KOPUNECZ, P., 2010: Quality survey of purchased milk in 2009. (In Czech) ČMSCH a. s., January, Praha.

KOVÁŘOVÁ, K., LEDVINKA, Z., SAMEK, M., VOJÁČEK, P., 2005: The trend functions and correlation regressional relationships of milk quality parameters. (In Czech) Sborník: XXXII. seminář o jakosti potravin a potravinových surovin. Brno MZLU, 20.

KUPKA, K., 1997: Statistical control of quality. (In Czech) TriloByte. ISBN 80-238-1818-X, 119.

MACEK, A., HANUŠ, O., GENČUROVÁ, V., VYLETĚLOVÁ, M., KOPECKÝ, J., 2008: The relations of sheep's and cow's freezing point of milk to its composition and properties. Sci. Agric. Boh., 39, 4, 329-334.

MELOUN, M., MILITKÝ, J., 1992: Statistical processing of experimental data by personal computer. (In Czech) Díl IIA, Pardubice, 102.

MELOUN, M., MILITKÝ, J., 1994: Statistical processing of experimental data. (In Czech) Plus spol. s r.o..

MILCHPRÜFRING BAYERN: Tätigkeitsbericht, 1993, 1994 and 1995.

ORDER 638/2004 about veterinary demands on milk and milk products (In Czech).

ORDER 1234/2007 (In Czech).

PECHOVÁ, A., ILLEK, J., PAVLATA, L., 2000: Factor affecting the fat concentration in cow milk. (In Czech) Veterinářství, 6, 238-24l.

RASMUSSEN, M. D., BJERRING, M., 2005: Development of bulk milk quality from herds with automatic milking system. 26th-28th April, ICAR Technical Series - No 10, Physiological and Technical Aspects of Machine Milking, Nitra, Slovak Republic, ISSN 1563-2504, ISBN 9295014-07-3, 71-86.

REGULATION 203/2003 Coll. about veterinary demands on milk and milk products.

REGULATION (EC) No. 853/2004.

ROHM, H., PLESCHBERGER, C., FOISSY, F., 1991: Der Gefrierpunkt pasteurisierter Milch in Österreich. Ernährung/Nutrition, 15, 11/12, 667671.

ROUBAL, P., KOPUNECZ, P., PEŠINOVÁ, H., et al., 2004, 2005: The evaluation of the raw milk quality in the central laboratories in the Czech Republic in 2003 and 2004. (In Czech) SCL pro hodnocení jakosti mléka, Praha, April and June, 19.

ROUBAL, P., SNÁŠELOVÁ, J., BUCHVALDKOVÁ, T., 2004: The freezing point of the raw and heat treated cow milk. (In Czech) Proceeding of seminar contributions of VÚCHS Rapotín: The actual problems of management in the cattle keeping, 71-76.

ŘEHĀK, D., RAJMON, R., KUBEŠOVÁ, M., ŠTÍPKOVÁ, M., VOLEK, J., JÍLEK, F., 2009: Relationships between milk urea and production and fertility traits in Holstein dairy herds in the Czech Republic. Czech J. Anim. Sci., 54, 5, 193200.

SCHULZ, T., 1997: Ohne formeln und Tabellen die Leistung gesteigert. Top Agrar, 5, 20-22.

TOMÁŠKA, M., HOFERICOVÁ, M., KOLOŠTA, M., 2005: The measurement of equivalent of milk freezing point. (In Slovak) Mliekarstvo, 36, 4, 7-9. 
WALSTRA, P., JENNESS, R., 1984: Dairy Chemistry and Physics, New York - Chichester - Brisbane Toronto - Singapore.
WIEDEMANN, M., BUCHBERGER, J., KLOSTERMEYER, H., 1993: Ursachen für anomale Gefrierpunkte der Rohmilch. 1 und 2. Mitteilung, $114,22,634-644,23,656-663$.

Address

doc. Ing. Oto Hanuš, Ph.D., AgriResearch Rapotín, Výzkumníků 267, 78813 Vikýřovice, The Czech Republic; doc. Dr. Ing. Josef Kučera, Radoslava Jedelská, Research Institute for Cattle Breeding Rapotín, Výzkumníků 267, 78813 Vikýřovice, The Czech Republic; Dr. Yunhai Zhang, Anhui Agricultural University, Department of Animal Sciences, College of Animal Science and Technology, Changjiang West Road 130, 230036 Hefei, P. R. China; Ing. Marek Bjelka, Ph.D., Breeders Cooperative Impuls, Bohdalec 122, 59522 Bobrová, The Czech Republic; Ing. Petr Roubal, CSc., Dairy Research Institute Ltd., Prague, Ke dvoru 12a, 16000 Praha 6, The Czech Republic 
